\title{
Egemenliğin Mali Yönü Olarak Farklı Açılardan Vergilendirme Yetkisi
}

Av. Dr. Ebubekir BAŞEL*

Makalenin Geliş Tarihi: 19.12.2020 Kabul Tarihi: 10.07.2021

Bu makale hakem incelemesinden geçmiştir ve TÜBİTAK - ULAKBİM Veri Tabanında indekslenmektedir.

DOI $10.30915 / \mathrm{abd} .978692$

* Avukat, Ankara Barosu. https://orcid.org/0000-0003-4328-1589 


\section{EGEMENLIĞíN MALI YÖNÜ OLARAK FARKLI AÇILARDAN VERGILENDIRME YETKISI}

\section{öz}

Egemenlik bir devletin ülke toprakları üzerindeki varlığını sağlayan unsurlardan biridir. Egemenliğin parçalarından biri olan mali egemenliğin temel unsuru ise vergilendirme yetkisidir. Vergilendirme yetkisi, devletin, ülkesi üzerindeki egemenliğine dayanarak vergi alma konusunda sahip olduğu hukuki ve fiili güçtür. Bu açıdan; vergilendirme yetkisine sahip olmayan bir yapı bağımsız bir devlet olarak nitelendirilemez. Vergilendirme yetkisinin kullanımı ülkeden ülkeye farklılık göstermektedir. Bu farklllıkların temel nedeni siyaset kuramlarında, devlet biçimlerinde ve siyasi rejimlerde-yönetim biçimlerinde var olan farklılıklardır. Bu bağlamda vergilendirme yetkisinin kullanımının anılan farklılıklarla derin bir ilgisi vardır. $\mathrm{Bu}$ farklıları ayrıntılandırmak anayasa hukuku ve vergi hukuku teorisi bakımindan faydalı olacaktır.

\section{Anahtar Sözcükler:}

Vergilendirme Yetkisi 


\title{
POWER TO TAX FROM DIFFERENT PERSPECTIVES AS THE FISCAL ASPECTS OF SOVEREIGNTY
}

\begin{abstract}
Sovereignty over the territory of the country is one of the elements that provide the existence of a state. The main element of fiscal sovereignty, which is part of the sovereignty, is power to tax. Power to tax is the judicial and actual power of state's. These powers are based on the sovereignty on countrywide about to levy taxes. From this perspective, a structure that does not have taxation authority can not be considered an independent state. The use of power to tax varies from country to country. The main reasons for these differences are the differences in political theories, state forms and political regimes. In this context, the use of power to tax has a deep interest in the noted differences. The elaboration of these differences will be useful in terms of constitutional law and tax law theory.
\end{abstract}

\section{Keywords:}

\section{Power To Tax}

Unitary State
Liberalism

Federal State

\section{Socialism}




\section{GíRiş}

Vergilendirme; asıl anlamı ile bir konu üzerinde vergisel bir yükümlülük ihdas etme anlamına gelir. Diğer anlamı ile de vergiyi doğuran olayın gerçekleşmesinden vergi tahsiline kadar olan süreci ifade eder. Vergilendirme yetkisi ise, vergilendirmenin bahse konu iki anlamını gerçekleştirebilmeyi sağlayan hukuki ve fiili güce sahip olmayı içerir. Vergi, modern devletin en önemli ve vazgeçilmez gelir kaynağı olduğundan vergilendirme yetkisi devletin asli ve vazgeçilmez yetkilerinden biridir.

Vergilendirme yetkisi temelde zor kullanma gücüne ve bu yönüyle devletin egemenliğine dayanır. Bu bakımdan vergilendirme yetkisi, genelde egemenlik, özelde mali egemenlikten kaynaklanmaktadır. Buradan hareketle vergilendirme yetkisine ve dolayısıyla mali egemenliğe sahip olmayan bir yapının devlet olarak nitelendirilmesi mümkün değildir.

Vergilendirme yetkisi; bir devlet için olmazsa olmaz yetki iken, bu yetkinin sınırsız bir biçimde kullanılması tarihsel süreç içerisinde birçok probleme neden olmuştur. İlk anayasacılık hareketlerinin ve ilk anayasanın ortaya çıması vergilendirme yetkisinin sınırlandırılmamış kullanımından kaynaklanmıştır. Temsili demokrasiye geçilmesi ve parlamentonun doğuşu da yine aynı nedenlere dayanmaktadır.

Vergilendirme yetkisi; farklı ülkelerde, değişik gelişim süreçleri geçirmiştir. Yetki, kimi ülkelerde, çok ciddi kırılmalara neden olmuşken, bazı ülkelerde hukuk devletinin genel gelişim sürecine paralel bir biçimde gelişme göstermiştir.

Vergilendirme yetkisinin kullanımı; siyaset kurmalarına, devlet biçimlerine ve siyasi rejimlere-yönetim biçimlerine göre farklılıklar göstermektedir. $\mathrm{Bu}$ çalışmanın amacı vergilendirme yetkisinin kullanımı; siyaset kuramları açısından (sosyalizm ve kapitalizm), devlet biçimlerine göre (üniter ve bileşik devletler) siyasi rejimlere-yönetim biçimlerine göre (demokratik ve antidemokratik) ayrı ayrı değerlendirmektir. Bu değerlendirme sırasında karşılaştırmalı hukuktan yararlanılacak ve çeşitli ülke anayasalarıyla örneklemeler yapılacaktır.

\section{1- Vergilendirme Yetkisi}

\subsection{Vergi Kavramı}

Vergi insanlık tarihi kadar eskiye dayanmakla beraber 'vergi-tax' kelimesi ilk kez 14.yüzyıl İngiltere'sinde kullanılmıştır. Tax latincede 'değer' anlamında kullanılan 'taxare' kelimesinden gelmektedir. Daha sonraları tax kelimesi ile görev anlamındaki 'task' kelimesi aynı anlamda kullanılmaya başlanmıştır. $\mathrm{Bu}$ 
anlamıyla vergi bir görevin yüklenilmesini ifade eder. ${ }^{[1]}$

Vergi, köken itibarıyla kabile reisi, derebeyi veya krallara ahlaki veya dini nedenlerle gönüllü olarak verilen bir çeşit hediye veya yardım niteliğindedir. Ancak zamanla devlet egemenliğini ellerinde bulunduranlar bazı sosyal sınıflardan mali yardım talep etmişlerdir. Mali yardımların zorunlu hale gelmesi ile üstünlük hediyeyi verenden alana geçmiştit. ${ }^{[2]}$

Merkezi devletlerin gelişimiyle, hediye ve yardımların yetersizliğinin ortaya çıkmasıyla ve vergi, şekli ve maddi olarak bir görev halini almıştır. Vergi niteliğinde olan ödemeleri ifade etmek üzere çeşitli zamanlarda kullanılan 'yardım', 'rica', 'hediye' gibi anlamlara gelen kelimelerin yerine, daha sonraları 'vazife', 'fedakârlık' ve nihayet gelişimin son safhasında 'zorunluluk' anlamına gelen kelimeler geçmiştir. ${ }^{[3]}$

Devletler başlangıçta sadece devletin klasik fonksiyonlarını gerçekleştirmek için gereken masrafları karşılamak üzere az miktarda vergi toplamışlardır. Ancak zaman ilerledikçe vergi yükünü gitgide artırmışlardır. Özellikle 1945’lerden 1980'lere uzanan dönemde, refah devleti kavramının gelişmesi ve yaygınlaşması ile sosyal refah önlemleri alınmaya başlanmış, bu ise devletlere çok ağır yükler getirmiştir. Bu yükün karşılanması amacıyla vergilendirilebilir kapasitenin mali sınırına ulaşılmışıı. Bu dönemde devletler sosyal amaçlarla vergi nevilerini sürekli çeşitlendirmiş ve vergi oranlarını artan oranlı hale getirmişlerdir. ${ }^{[4]}$

Dönemsel olarak anlamında değişimler yaşansa da vergi kamusal ihtiyaçların karşılanması amacıyla özel kesimden kamu kesimine, hukuki zorlamaya dayanılarak karşılıksız ve kesin olarak yapılan, para ile ifade edilebilen bir aktarımdır. ${ }^{[5]}$ Türk Anayasa Mahkemesi de benzer bir tanımı esas almıştır. Mahkeme'ye göre vergi kamusal gereksinimleri karşılamak için kişi ve kuruluşların mal varlıklarının bir bölümünün devlete geçirilmesi, bu yolla kamuya aktarılmasıdır. ${ }^{[6]}$

Alman Vergi Usul Kanunu’nda vergi herhangi bir hizmet karşllı̆̆ olmayan

[1] https://www.ldoceonline.com/dictionary/tax , (İ.E.T: 28.9.2020)

[2] Turhan, S. (1982). Vergi teorisi. İstanbul: Elektronik Ofset Matbaası, s. 2.

[3] Schmölders, G. (1982). Genel vergi teorisi. (Çev. Salih Turhan), (4. Baskı) İstanbul: Fakülteler Matbaası, 4, Turhan, Vergi teorisi,s. 2.

[4] Özdemir, S. (2007). Küreselleşme sürecinde refah devleti. (2. Bask1), İstanbul: Entegre Matbaacılık, İstanbul Ticaret Odası Yayın No: 57, s. 208.

[5] Kaneti, S. Vergi hukuku, (2. Baskı), İstanbul: Filiz Kitabevi, s. 4, Turhan, a.g.e., s. 27.

[6] Anayasa Mahkemesi, E:1989/6, K:1989/42 R.G.: 06.04.1990 20484. 
ve bir kamu tüzel kişisi tarafından gelir temin etmek üzere, kanunun bağladığı olay ile münasebet halinde bulunan herkesten bir defalığına veya devamlı olarak alınan para ödemeleri olarak tarif edilmiştir. ${ }^{[7]}$ Vergi kendisini ödemekle yükümlüler için borç, tahsil etmesi gereken kamu için ise alacak niteliğindedir.

Verginin hukuki mahiyetini ve esasını açıklamaya çalışan teoriler fayda teorisi ve ödeme gücü teorisi olarak ikiye ayrılmaktadır. Faydalanma (istifade) teorisi rasyonalist ferdiyetçi devlet görüşüne dayanmaktadır ve kendi içinde üçe ayrılmaktadır. Bunlardan birincisi vergiyi devlet ile birey arasında bir değişim ilişkisinin aracı diğer bir anlatımla devletten alınan kamu hizmetinin bedeli sayan görüştür. Diğeri ise vergiyi sigorta primine benzeten görüştür. Son görüş ise vergiyi genel giderlerin karşılığı saymaktadır. ${ }^{[8]}$

Organik-kolektivist devlet görüşüne dayanan ödeme gücü teorisi ise vergiyi devletin sağladığı hizmetlerin bir fiyatı gibi kabul etmenin yetersiz olduğu fikrine dayanır. Bu teoride verginin devlet ile bireyin karşılıklı anlaşmasından ziyade devletin egemenlik yetkisinden kaynaklandığı düşünülür. ${ }^{[9]}$

Verginin temel olarak üç fonksiyonu vardır. Birincisi verginin klasik fonksiyonudur ve bu fonksiyon mali fonksiyon olarak da adlandırılır. Verginin mali fonksiyonu vergilerin kamu harcamalarını karşılanması için alınmasıdir. $^{[10]}$ Verginin ekonomik fonksiyonu ise müdahaleci devlet anlayışının sonucudur ve verginin ekonomiyi yönlendirmesini esas alır. Bu rolü ile vergi, yatırımları teşvik etmek, üretim ve tüketimi teşvik etmek ya da kısıtlamak, tasarrufu teşvik etmek gibi amaçlar için kullanılabilir. ${ }^{[1]}$ Verginin sosyal fonksiyonu ise gelir ve servet dağılımının adaletli bir şekilde sağlanmasını amaçlar. Artan oranlı vergiler, muafiyet ve istisnalar bu fonksiyonun araçlarındandır. ${ }^{[12]}$

1982 Anayasası'nın 73. Maddesi'nde verginin tanımı yapılmamış, onun yerine vergi ödevinden söz edilmiştir. 73. madde de 'Herkes kamu giderlerini karşılamak üzere mali gücüne göre vergi ödemekle yükümlüdür. Vergi, resim ve harçlar ve benzeri yükümlülükler ancak kanunla konulur, değiştirilir veya kaldırılır.' hükmü yer almıştır.

[7] Schmölders, a.g.e., s. 65.

[8] Turhan, a.g.e., s. 17-23.

[9] Turhan, a.g.e., s. 23-25.

[10] Schmölders, a.g.e., s. 69.

[11] Turhan, S. (1975). Vergileme ve iktisadi büyüme. İ.Ü. Maliye Enstitüsü Konferanslar1, Seri: 23, İstanbul, s. 249.

[12] Aksoy, Ş. (1998). Kamu mâliyesi. (3. Baskı), İstanbul: Filiz Kitabevi, s.174. 
Verginin genel teorisi anlamında 1982 Anayasası'nın bu düzenlemesi; verginin kamu giderlerini karşılamak için otorite tarafından zorunlu olarak alınması, para ile ödenmesi ve karşılıksız olması gibi başlıca özelliklere yer vermiştir. Bunlar dışında madde metninden çıkan diğer sonuçlar verginin genel teorisi dışındadır. Örneğin verginin kanuniliği bir vergiden bahsedebilmek için zorunlu bir şart değildir. Diğer bir anlatımla vergi her ülkede kanunla alınmayabilir veya mali güçle orantılı olmayabilir.

\subsection{Vergilendirme ve Vergilendirme Yetkisi}

\subsubsection{Vergilendirme Kavramı}

Vergilendirme (taxation, taxing assesment) kavramının tanımına Türk doktrininde yer verilmemiştir. Doktrinde daha çok vergilendirme yetkisi kavramı üzerinde durulmuştur. Ancak vergilendirme kavramının ne olduğunun ve bu kavramdan ne anlaşılması gerektiğinin ortaya konulması gerekmektedir. Amerikalı ünlü yargı̨̧ ve akademisyen Thomas McIntyre Cooley, 1876 'da vergilendirmeyi ortak ihtiyaçlar için gelir artırma yolu olarak tanımlamıstır. Vergilendirme kavramının egemen güç olan hükümetin kamu harcamalarını finanse faaliyetini ifade için kullanıldığım belirtmişti. ${ }^{[13]}$

Vergilendirme para ile ifade edilebilen değerlere farklı ama makul kıstaslar uygulanarak bu değerlerin bir kısmının vergi olarak alınması faaliyetidir. $\mathrm{Bu}$ noktada vergilendirmenin iki farklı anlamı ortaya çıkmaktadır. Bunlardan ilki vergilendirmenin asıl anlamıdır. Vergilendirme; ilk ve asıl olarak bir konu üzerinde vergisel bir yükümlülük ihdas etme anlamına gelmektedir. Bu konu bir kişi, bir eşya olabileceği gibi bir fiil de olabilir. Bu anlamıyla vergilendirme vergi koyma iktidarıdır. Bir fiilde bulunma veya bir sahipliğin karşılı̆̆ olarak bireylerden parayla ifade edilebilen bir değerin alınmasına karar verilmesi vergisel bir yükümlülük ihdas etme anlamına gelir. Vergisel yükümlük ihdas edilen konu veya konuların bir kısmının vergiden bağışık tutulması gene vergilendirme kavramının içerisindedir. Diğer yandan yükümlük ihdas edilen konu veya konuların değiştirilmesi veya kaldırılması da vergilendirme niteliğindedir. Türk Anayasa Mahkemesi eski kararlarında benzer bir görüşü paylaşmıştır. Anayasa Mahkemesine göre vergi koyma kavramı içine, konulan vergi veya malî yükümden bağışı tutma, değişiklik yapma kavramı da girmektedir. ${ }^{[14]}$

[13] Cooley,T. M. (1876) A treatise on the law of taxation including the law of local assessments, Callaghan and Company, aktaran Herman M. K. (1938). The power to tax, 22 Marq. L. Rev. 125, s.1.

[14] Anayasa Mahkemesi, E: 1967/41 K: 1969/57, R.G.:12.3.1971/13776. 
Bir malın veya hizmetin teslimi veya bir mala veya statüye sahip olma vergilendirmenin konusunu oluşturabilir. Örneğin harcamalar üzerinden alınan vergilerde bir malın teslimi verginin konusu olabilirken bir araca sahiplik, servet vergisinin konusu olur. Mali yükümlülüklerin vergi resim harç ve benzeri isimlerle nitelenmesi vergi olma niteliğini etkilemez. Örneğin bir sözleşmenin imzalanması nedeniyle alınan vergi ile kamu kurumlarından alınacak bir hizmet karşılığı istenilen bedellerin alınma gerekçeleri farklı olsa da her ikisi devlet tarafından zorlama gücüne dayalı olarak alınmakta olduğundan vergisel niteliktedir.

Vergilendirmenin diğer ve ikinci anlamı ise vergilendirmenin bir süreci ifade etmesidir. Vergilendirmenin kısa tanımında ifade edildiği üzere para ile ifade edilebilen değerlere farklı kıstaslar uygulanarak bir kısmının vergi olarak alınması faaliyeti genellikle bir sürece yayılmaktadır. Genellikle vergiyi doğuran olayın gerçekleşmesi, üzerinden vergi alınacak miktarın yani matrahın hesaplanması, belirlenen matraha belli bir oranın uygulanarak alınacak verginin hesaplanması ve verginin tahsili aşamalan vergilendirme sürecinin parçalarıdır.

\subsubsection{Vergilendirme Yetkisi Kavramı}

Vergilendirme yetkisi (power to tax, taxation power, taxing power, tax power), vergi ihdas etme hakkına sahip olmayı ve vergilendirme aşamalarını yürütebilecek mekanizma ile güce sahip olabilmeyi ifade etmektedir. Devletin zorlama gücü vergilendirme yetkisinin kullanımı için olmazsa olmazdır ve bu yetkinin ana karakterini oluşturur.

Vergilendirme yetkisi devletin ülkesi üzerindeki egemenliğine dayanarak vergi alma konusunda sahip olduğu hukuki ve fiili güç olarak da tanımlanmıştır. ${ }^{[15]}$ Türk Anayasa Mahkemesi de kararlarında bu tanıma vermektedir. ${ }^{[16]}$ Mahkemeye göre vergilendirme yetkisi, devletin, ülkesi üzerindeki egemenliğine bağlı olarak, vergi alma konusunda sahip olduğu hukuksal ve fiili güçten kaynaklanmaktadır. ${ }^{[17]}$ Vergilendirme yetkisi egemenliğin doğasından gelmektedir ve bağımsız her hükümetin hakkıdır. ${ }^{[18]}$

Diğer bir tanımda ise vergilendirme yetkisi, devletin egemenlik gücüne dayanarak ya da halktan aldığı yetkiye dayanarak diğer kamu kuruluşlarının mali ve mali olmayan amaçları gerçekleştirmek üzere anayasal çerçevede vergi,

[15] Çağan, N. (1982). Vergilendirme yetkisi. İstanbul: Kazancı Hukuk Yayınları, s. 3.

[16] Anayasa mahkemesi, E: 2010/93, K: 2012/20, R.G.: 26.07.2013-28719.

[17] Anayasa mahkemesi E: 2008/110 K:2010/55, R.G.: 21.06.2010-27619.

[18] Herman, a.g.e., s. 1. 
resim, harç ve benzeri mali yükümlülükleri alma konusunda sahip oldukları hukuki ve fiili gücü kullanabilmesi olarak tanımlanmıştır Türk Anayasa Mahkemesi vergilendirme yetkisini devletin üstün kamu gücüne dayanan bir kamu hukuku ilişkisine dayalı olarak kamu hizmetlerinin finansmanı amacıyla vatandaşlarının gelir ve/veya servetine ortak olması olarak tanımlamaktadır. ${ }^{[19]}$

Vergilendirme yetkisine sahip olmayan bir yapıdan devlet olarak söz edilemez. Bu yetki devletin mali egemenliğinin içerdiği yetkilerin en önemlisidir. Devlet kamu hizmetlerinin görülmesi için gereksinim duyduğu mali kaynakları bu yetkiyi kullanarak karşılar. ${ }^{[20]}$ Vergilendirme yetkisi egemenliğin ayrılmaz bir parçası olduğundan, bu yetkiye sahip olmak hükümetler için olmazsa olmazdır. ${ }^{[21]}$

Vergilendirme yetkisi, vatandaşlar için devletin mali egemenliğinin ve zor kullanma gücünün en belirgin göstergesidir. Bu yetki ile devlet gerçek ve tüzel kişilere ait parasal değerlerin bir kısmının kendisine aktarılmasını sağlamaktadır. ${ }^{[22]}$

Vergilendirme yetkisinin hukuki niteliği devlete verilen anlamın farklılaşması ile paralel olarak değişmiştir. Örnek olarak kamunun faiz borcunu kapamak maksadıyla vergi toplayan bir devlette hâkim olan vergilendirme anlayışı ile iç, dış güvenlik ve adalet hizmetlerinin finansı için vergi toplayan bir devlette hakim olan vergilendirme anlayışı birbirinden farklıdır. Bu bağlamda devletin üstlendiği görevlerin değişmesine paralel değişen bir vergilendirme anlayışının olduğu görülmektedir. ${ }^{[23]}$

Jandarma devlet ${ }^{[24]}$ anlayışının egemen olduğu on yedinci yüzyılda devletin gücü oranında vergilendirme yetkisine sahip olduğu düşünülmüştür. On sekizinci yüzyılda ise rasyonalist ferdiyetçi devlet kuramının etkisiyle vergilendirme devletin verdiği hizmetten yaralanmanın karşllığı olarak, istifade

[19] Anayasa Mahkemesi E:2009/39, K: 2011/68 R.G.:15.10.2011-28085.

[20] Öncel, M., Çağan, N., Kumrulu, A. (1985). Vergi hukuku. (Cilt: 1 Genel Kısım), (2. Bası), Ankara: Ankara Üniversitesi Siyasal Bilgiler Fakültesi Yayınları, s. 39.

[21] Union Refrigerating Transit Co. v. Kentucky, 199 U.S. 194 (1905). aktaran Herman M. Knoeller, The Power to Tax, 22 Marq. L. Rev. 125 (1938). s. 1.

[22] Brennan, G., Buchanan, J. M. (1980). The power to tax - analytical foundations of a fiscal constitution, Cambirdge:Cambridge University Press, s. 8.

[23] Schmölders, Genel vergi teorisi, s. 67.

[24] Devletin sadece güvenlik, savunma, adalet, eğitim ve diplomasi görevlerini yerine getirmesi ve piyasaya hiçbir müdahale etmemesi gerektiği düşüncesine dayanan devlet anlayışıdır. 
kuramı ile açılklanmıştır. On dokuzuncu yüzyıl başlarında organik kolektivist devlet kuramı etkisi ile vergilendirme fedakârlık ve ulusal görev olarak değerlendirilmiştir. Günümüzde egemen olan anlayışa göre, vergilendirme, devletin egemenlik yetkisine dayandırılmıştır. Bunun yanında siyasal ve ekonomik düzen farklılığına bağlı değişkenlikler olabileceği de kabul edilmiştir. ${ }^{[25]}$

\subsubsection{Vergilendirme Yetkisinin Kapsamı}

Vergilendirme yetkisi kapsam olarak ikiye ayrılabilir. Bahse konu ayrım vergilendirme yetkisinin kullanım alanı ile ilişkilendirilmiştir. Bu ayrıma göre salt vergi toplamaya yönelik olarak kullanılan vergilendirme yetkisi dar anlamda kullanılmaktadır. Vergi yanında benzeri mali yükümlülükleri toplamayı içeren vergilendirme yetkisi ise geniş anlamda kullanılmaktadır. Resimler, harçlar, katılma payları, ücretlerin toplanması geniş anlamda vergilendirme yetkisi kapsamındadır. Bunun yanında sosyal kamu kurumlarına ve kamu kurumu niteliğindeki meslek kuruluşlarına yapılan ödemelerin, verilen aidatların bu kapsamda olduğu ileri sürülmektedir. ${ }^{[26]}$ Bu noktada belirleyici husus tüm bu ödemelerin devletin sahip olduğu zorlama gücünün eseri olmalarıdır.

Dar ve geniş anlamda vergilendirme yetkisinin diğer bir farkı da kamu hizmetinden yararlanılmasında ortaya çıkmaktadır. Dar anlamda vergilendirme yetkisinde kamu hizmetinden doğrudan bir yararlanmadan söz edilemez. Örneğin iç ve dış güvenlik gibi tam kamusal hizmetlerde bireysel fayda ölçülemez. Diğer bir anlatımla bu hizmetlerin finansmanı dar anlamada vergilendirme yetkisi ile sağlanmaktadır. ${ }^{[27]}$

Geniş anlamda vergilendirme yetkisi ise genellikle karşılık ve yararlanmanın sonucu olarak ortaya çıkmaktadır. Yarı kamusal hizmetler genellikle ilgililerin isteği üzerine sunulmakta olup ilgililerden yararlanmaları karşılığında genel olarak bir bedel de alınabilir. Bu bedeller dar anlamda vergilendirmenin dışındadır.

\subsubsection{Vergilendirme Yetkisinin Kaynağı}

Vergilendirme yetkisinin kaynağını egemenlik oluşturmaktadır. Devlet kamusal ihtiyaçları karşılamak maksadıyla vergi alma yetkisine sahiptir. Bu yetkinin asıl kaynağı ise devletin sahip olduğu egemenlik yetkisidir. Verginin zorunlu ve karşılıksız olma özelliği de göz önünde bulundurulduğunda bu tür

[25] Çağan, a.g.e., s. 4.

[26] Çağan, a.g.e., s.5.

[27] Arıkan, Z. (1994). Demokratik gelişim sürecinde vergilendirme yetkisinin kullanımı ve sınırları (Türkiye analizi). Yayımlanmamış Doktora Tezi, D.E.Ü.S.B.E. İzmir, s.8. 
bir yükümlülük ancak devletin egemenlik gücüne dayanılarak tesis edilebilir. ${ }^{[28]}$

Egemenlik kavramı farklı anlamlarda kullanılabilmektedir. Bu ise egemenliğin nispi bir karaktere sahip olduğunu göstermektedir. ${ }^{[29]}$ Egemenlik bir kudretin, bir iktidarın en üstün olma vasfı, başkalarına emir ve direktifler vererek sözünü geçirme ve onlara karşı üstünlük kurabilme olarak tanımlanabilir. ${ }^{[30]}$

Soyut ve ideolojik bir kavram olan egemenlik, devletin varlık koşuludur. Devletin, sınırsız ve koşulsuz bağımsızlığa sahip olması ve ülke içinde kendine rakip başka bir gücün bulunmaması anlamına gelen egemenlik, devlet içindeki en üstün buyurma kudretidir. ${ }^{[31]}$ Belirli bir toprak parçası üzerinde yaşayan ve ortak özellikleri olan insan topluluğunun devlet olarak nitelenebilmesi için, bu topluluk üzerinde, tek ve üstün bir siyasi otorite gereklidir. Üstün ve sınırsız olan bu güç, egemenliktir. Egemenlik emir, kumanda ve yaptırım uygulama yetkisi şeklinde kendini gösterir. ${ }^{[32]}$

Egemenlik bir devletin olmazsa olmaz vasfı aynı zamanda devlet yetkilerinin kullanımını sağlayan güçtür. Bu güce sahip olan devlet kendisinin varlık nedeni olan tüm sorumluklarını bu güçle yerine getirir. Devletin varlık nedenlerinden birisi ise kamusal ihtiyaçların karşılanmasıdır. Devlet kamusal ihtiyaçları vergilendirme yetkisi ile finanse eder. Bundan dolayı vergilendirme yetkisinin kaynağ devletin mali egemenliğidir. ${ }^{[33]}$ Mali egemenlik, egemenlik kavramının mali alandaki karşılı̆̆ıdır. Devlet egemenliği gibi mali egemenliğin boyutları da geniş ve kapsamlıdır. Zira mali egemenlik, egemenliğin tamamlayıcısı ve ayrılmaz bir parçasıdır. Devletler vergilendirme yetkilerinin sınırlarını kendilerini belirledikleri ölçüde mali egemenliklerine sahip olabilirler. ${ }^{[34]}$

Bir devletin tam bir mali egemenliğe sahip olması için, ülkesinin tamamı üzerinde bütün mali hizmetlerin kendi elinde merkezîleştirilmesi, tüm gelir-

[28] Arıkan, a.g.t., s. 3.

[29] Akyılmaz, B. (1998). Milli egemenlik kavramının gelişimi, Gazi Üniversitesi Hukuk Fakültesi Dergisi, Prof. Dr. İhsan Tarakçıŏlu’na Armağan, 2, ss. 213 222, s.213.

[30] Özman, M. A. (1964). Devletlerin egemenliği ve milletlerarası teşekküller, A.Ü.H.F.D., 21(1 4), s. 56.

[31] Özbudun, E. (2004). Türk Anayasa Hukuku, (8. Baskı), Ankara: Yetkin Yayınları, s. 83.

[32] Akyllmaz, a.g.m., s. 213.

[33] Arıkan, a.g.t.,s. 4.

[34] Özpençe, A. İ., Özpençe, Ö. (2007). Küreselleşme ve uluslararası kuruluşların ulus devletin vergilendirme yetkisine etkileri. International Journal of Human Science, 4(1), s. 
lerin kendi hazinesine girmesi ve harcamaların kendisi tarafından yapılması gerekmektedir. $^{[35]}$

Egemenlik tüm devletlerin ortak özelliği olmakla birlikte her devletin farklı bir yönetim biçimi olabilir. Siyasi iktidarın kullanılış biçimi devletin mali egemenlik yetkisini kullanımını da belirler. Bu bağlamda mali egemenliğin kullanımı devletlere, yönetim biçimlerine ve siyasal iktidar yaklaşımlarına göre değişkenlik gösterebilir.

\section{Farklı Açılardan Vergilendirme Yetkisi}

\subsection{Siyaset Kuramları Açısından Vergilendirme Yetkisi}

\subsubsection{Genel Olarak}

Vergilendirme ile ilgili olarak siyaset kuramları genel olarak sosyalizm ve kapitalizm olarak ikiye ayrilabilir. Sosyalizm, genel olarak sosyal devletin tamamıla yanındadır, kamu önlemlerini destekler, kolektivisttir ve kurumsal sosyal devleti anlayışını, yani iyileştirmeden çok önlemeye yönelik yaklaşımı benimser. Kapitalizm ise, sosyal devlete karşıdır, aynı şekilde kamu önlemlerine karşıdır, bireyselcidir ve residual (kalıntı) sosyal devleti yani insan ihtiyaçları karşılanmadığı takdirde bu ihtiyaçların devlet kurumlarının sosyal hizmetleri ile karşılanmasını benimser. Ancak bu görüşlerin çok net bir biçimde ayrılması her zaman söz konusu değildir. Bireyselci sosyalist görüşler yanında, kolektivist kapitalistler de vardır. Birçok sosyalist görüş sahibi kurumsal sosyal önlemlerinden rahatsızken, kapitalist görüş sahibi birçok kişi de kurumsal sosyal devlet ilkelerini kabul etmektedir. ${ }^{[36]}$

Kapitalizm ve sosyalizm sistemlerinin, kendine özgü politik ve ekonomik örgütlenme modeli söz konusudur. Kapitalizmin ekonomik örgütlenme türü piyasa ekonomisi (liberalizm), diğerininki ise sosyalist (otoriter) ekonomi (merkezi planlama, komuta ekonomisi) dir. Bir de, bu ikisinin ortasında karma ekonomi (devletçilik, sosyal devlet) yer almaktadır. ${ }^{[37]}$

Temel siyaset kuramlarını genel olarak açıkladıktan sonra bunların devletin vergilendirme yetkisini nasıl ele aldıklarını açıklamaya çalışacağız.

[35] Feyzioğlu, B. (1984). Nazari, tatbiki, mukayeseli bütçe, İstanbul: Filiz Kitabevi, s. 15.

[36] Spicker, P. Thepolitics of welfare, an introduction to socialpolicy. http//www2.rgu. ac.uk/publicpolicy/ introduction/politics.htm, 13.03.2003, s. 1, aktaran Özdemir, a.g.e., s.44.

[37] Özdemir, a.g.e., s.45. 


\subsubsection{Kapitalizm (Liberalizm) ve Vergilendirme Yetkisi}

Batı dünyasında 19. yüzyılda yaşanan iki önemli gelişme, kapitalizmin doğmasına yol açmıştır. Bu gelişmelerden birisi, makinenin üretim sürecine katılımını sağlayan sanayi devriminin gerçekleşmesi, ikinci si ise, üretim ve ticaret özgürlüğ̈ ile ekonomik liberalizmi getiren Fransız Devrimi'dir. ${ }^{[38]}$

Liberalizmde vergilendirme yetkisi karşılık ve mübadele ile açıklanmaya çalışılmıştır. ${ }^{[39]} \mathrm{Bu}$ görüş rasyonalist-ferdiyetçi ve faydacı devlet anlayışından hareket etmektedir. Buna göre vergilendirme vergi alacaklısı ile vergi yükümlüsü arasında bir çeşit değişim olarak kabul edilmekte, verginin karşılıksız olma karakteri göz ardı edilmekte, bireyin vergi ödemeleriyle devletçe sunulan hizmetler arasında bir mübadele eşitliğinin olduğu farz edilmektedir. [40]

Liberal iktisadi düşünceye göre liberal devletin temel görevi iç ve diş güvenliğin sağlanmasıdır. Vergi ise devletin sunduğu bu hizmetlerin karşılığıdır. Serbest piyasada, nasıl bir mal veya hizmet karşılığı bir bedel ödenirse, bunun gibi devletin sağladığı kamu hizmetleri nedeniyle fertlerin bu hizmetlerden edindiği fayda derecesinde vergiler alınacaktır. ${ }^{[41]}$

Liberalistlere göre vergilendirmenin ölçüsünü devletin masrafları tayin edecektir. Bu nedenle devletin masraflarının sınırlı olması, diğer bir anlatımla devletin piyasada hiçbir iş yapmaması gerektiğini savunurlar. Böylece devletin görevleri azalacağını, bunun sonucunda masrafların azalacağını, bu yolla verginin en aza indirileceğini ifade ederler. Öte yandan verginin tasarrufun önünde engel olduğu, vergilerin minimize edilmesiyle sermaye birikiminin kolaylaşacağı iddia edilir. Devlet vergilendirme yetkisini mükellefi en az taciz edecek şekilde kullanmalıv ve düzenlemelidir. Bunun için vasıtalı vergilere ağırlık verilmeli, vasıtasız vergiler mükellefi en az rahatsız edecek şekilde organize edilmelidir. Liberallere göre en zararlı vergiler, veraset ve gelir vergileri gibi zenginler üzerinden alınan ve tasarrufa engel olan vergilerdir. ${ }^{[42]}$ Liberal teorinin fikir babası Adam Smith devlet gelirlerini ayrıntılı bir şekilde incelemiş ve çeşitli vergileme ilkeleri belirlemiştir. Smith; kamu hizmetinin finansmanında olağan ve temel gelir kaynağı olarak gördüğü vergilendirmeye ilişkin dört ana ilke ortaya koymaktadır. ${ }^{[43]}$

[38] Göze, A. (1995). Liberal marxiste faşist nasyonal sosyalist ve sosyal devlet.(3. Baskı), İstanbul: Beta Yayınları, s. 9.

[39] Öncel, Çağan, Kumrulu, a.g.e., s. 39.

[40] Turhan, a.g.e., s. 18.

[41] Erginay, A. (1976). Kamu maliyesi, (5. Bas1), Ankara, s. 30.

[42] Sur, F. H., (1950). Liberallere göre maliye, A.Ü.H.F.D, 7(3-4) s.567-572, s.568-571.

[43] Savaş, V. F. (2000). İktisadın tarihi, (4. Bask1), Ankara: Siyasal Kitabevi, s. 294. 
- Her birey hükümet giderlerine mümkün olduğu kadar ödeyebileceği oranda bir başka ifade ile devletin koruması altında kullanabildiği geliri oranında katkıda bulunmalıdır. (Eşitlik ilkesi) ${ }^{[44]}$

- Her bireyin ödemek zorunda olduğu vergi kesin olmalı, keyfi olmamalıdır. (Kesinlik / Belirlilik ilkesi)

- Her vergi mükellef için en uygun zaman ve biçim dikkate alınarak düzenlenmelidir. (Uygunluk ilkesi)

- Vergi toplama maliyetleri (vergi harcamaları) mümkün olduğu kadar az olmalıdır. (Etkinlik / Ekonomiklik ilkesi) ${ }^{[45]}$

\subsubsection{Sosyalizm ve Vergilendirme Yetkisi}

Sosyalist devlette rekabetin gerçekleşeceği bir piyasa sistemi mevcut değildir, merkezi planlama ve bir dağıtım sistemi söz devlet tarafından belirlenmektedir. Sosyalizmin, aynı zamanda sosyal devletin gelişme tarihine bakıldığında sanayi devrimiyle birlikte ortaya çıkan yoksul sınıfların, sınıf bilinci kazanıldıkça, kendileri açısından kapitalizmi bir tehlike olarak gördükleri ve onu değiştirmek ve dönüştürmek için hareket etmeye başladıkları görülmektedir. Bu hareketin bir ucu proletarya devriminin gerekliliğine kadar gitmekte, devletin ele geçirilmesi ve yıkılması (sosyal devrim) hedeflenmektedir. Diğer yandan, bazıları içinse, devlete nüfuz edilmesi ve onun değiştirilmesi (sosyal reform) yeter li olarak görülmektedir. Sosyalizmde gelir ve diğer kaynakların dağıtımı üzerinde halk adına kontrol sahibi olan sosyalleştirilmiş bir ekonominin, dağıtım adaleti problemini yapısal seviyede çözeceğine inanılmaktadır. ${ }^{[46]}$

Sosyalistlere göre devletin bütçesinin vergiler ve borçlanmadan oluşturulması hatalı olup bütçeyi karmaşık hale getirmektedir ve bu karmaşıklık kapitalist tarih boyunca büyümüştür. İki sınıflı yapıların egemen olduğu devlette vergilendirmeye karar veren kapitalist sınıftır ve bu sınıfça alınan kararlar işçi sınıfının aleyhine olmaktadır. Kapitalistlerin devletin herkesin ortak paydası olduğu ve herkesin devlete vergi yoluyla katkı yapması gerektiği iddiası hatalıdır. Kapitalistlerce kira, faiz ve kardan ödenen vergi işçi sınıfının ödenmemiş emeği olup esasında vergiler iş̧̧i sınıfınca ödenmiş olmaktadır. ${ }^{[4]}$

[44] Çalçalı, Ö. (2013). Kamu maliyesi perspektifinden Adam Smith, Uluslararası İktisadi ve İdari Incelemeler Dergisi, 6(11), s.100.

[45] Smith, A. (2011). Milletlerin zenginliği. (Çev. Haldun Derin), İstanbul: Türkiye İş Bankası Kültür Yayınları, s. 927930.

[46] Özdemir, a.g.e., s. 55.

[47] http://www.worldsocialism.org/spgb/printpdf/book/export/html/4167 24.2.2014)

(İ.E.T. 
Marx ve Engels'te ilerici vergilendirme fikri vardır. İlerici vergilendirme de burjuvanın elindeki bütün üretim araçlarının ve sermayenin devletleştirilmesi gerekir. Sosyalizmin başarısızlı̆̆ına karşın ilerici vergilendirme fikrinin sosyal devlet fikrine kaynaklık ettiği iddia edilmiştir. ${ }^{[48]}$

Sosyalistlere göre vergilendirmede üç temel prensip izlenmelidir. Öncelikle dolaylı vergiler azaltılmalı ve doğrudan vergiler artırılmalıdır. Çünkü doğrudan vergiler mali güce göre vergilendirmenin doğal sonucudur ve iş̧̧i sınıfının lehine sermaye sınıfının ise aleyhinedir. İkinci olarak vergilendirme toplumda hep artı değere sahip olan elit sınıfa yönelik olmalıdır ve onları ilgilendirmelidir. Son olarak ise işçi sınıfı devletin savunma harcamalarının artırılmasına bu yolla kendisinin vergilendirilmesine karşı çıkmalıdır. ${ }^{[49]}$

Sosyalizm uygulamalarına bakıldığında yukarıda yer verilen teorik yaklaşımların vergileme pratiği ile bazı yönlerden doğrulandığı görülmektedir. Örnek olarak Sovyetler Birliği uygulaması gösterilebilir. Sovyetler döneminde özel teşebbüsler nerdeyse yok denecek seviyede tutulmuştu. Üretim aşaması ise sadece devlet teşebbüsleri ve kooperatif teşekküllere bırakılmıştı. Bunun yanında özel istihdama izin verilmemekteydi. ${ }^{[50]}$ Bununla birlikte doğrudan vergilendirmeye ağırlık verilmesi hususu pratiğe geçirilememiştir. Üretim kaynaklarında farklılaşma olmaması ve benzeri nedenlerle gelir seviyesinde farklılaşma görülemediği için vasıtasız vergilendirmenin bir anlamı olamayacağından asıl olan vasıtalı vergilendirme olmuştur.

Sovyetlerde devletin ekonomik hayattaki ağırlığı \%98 seviyesinde idi. Çoğu durumda vergilendirme, sağ cepten alıp sol cebe koyma anlamındaydı. Vergilendirme çoğunlukla plansız (ad hoc) ve keyfi idi. Bunun sonucu olarak Sovyet Rusya’da vergi kültürünün neredeyse hiç var olmadığı söylenebilir. ${ }^{[1]}$

[48] Dorn, J. K. Ending tax socialism, http://www.cato.org/publications/commentary/ ending-tax-socialism (İ.E.T. 24.2.2014).

[49] Quelch, H. (1909). Socialism and taxation. Social Democrat, Vol. III, No.11 pp. 481-486; Transcribed: By Ted Crawford., https://www.marxists.org/archive/quelch/1909/11/taxation.htm (İ.E.T. 24.2.2014)

[50] Yuluğ, M. (1967). Sovyetler Birliği vergi sistemi. Maliye Araştırma Merkezi Konferanslar Dergisi, (13), s. 146-148.

[51] Birger. N. (2001). The emergence of tax culture in Russia, The 57th Congress of the International Institute of Public Finance: The Role of Political Economy in the Theory and Practice of Public Finance, s. 2. 


\subsection{Devlet Biçimlerine Göre Vergilendirme Yetkisi}

\subsubsection{Genel Olarak}

Biçimlerine göre devletler üniter devlet ve bileşik devlet olmak üzere ikiye ayrılmaktadır. Bileşik devletler de kendi içinde çeşitli ayrımlara tabi tutulmaktadır. Ancak vergilendirme bakımından önem arz eden ve uygulaması olan birleşik devlet, federal devlet (federasyon) dur. Bunlardan başka ne üniter devlet ne de federal devlet olarak değerlendirilemeyecek olan bölgesel devletler vardir.

Üniter devlet devletin temel unsurları olan ülke, millet ve egemenlik unsurunun tek olduğu devlete verilen isimdir. Üniter devletlerde egemenliği kullanan organlar teklik göstermektedir diğer bir anlatımla üniter devletlerde tek bir yasama tek bir yürütme ve tek bir yargı organı vardır. ${ }^{[2]}$ Egemenliği kullanan organların tekliği bu organların kendi içerisinde farklı biçimlerde teşkilatlanmasına engel değildir. Örnek olarak üniter devletlerde yargı erki tek olmasına karşın yargı içerisinde uzmanlaşma ve iş bölümüne dayanan yargı kolu ayrımının olması veya farklı bir teşkilatlanma modelinin uygulanması da imkân dâhilindedir. Aynı şekilde üniter devlette egemenliği kullanan organların tekliği idarenin teşkilatlanmasında merkez ve taşra teşkilatı ve hizmet ve yerel yerinden yönetim yapılanması oluşturulmasına engel değildir.

Bileşik devlete, iki veya daha çok devlet farklı nedenlerle birleşerek ayrı bir devlet oluştururlar. Bu birlikteliği oluşturan devletler egemenliklerini farklı yasama yürütme ve yargı organlarıla kullanabilirler. Federal devlette bileşik devletlerden olup uluslararası kişiliğe sahip bir merkezi nitelikli federal devlet ve uluslararası kişiliğe ve temsile sahip olmayan federe devletlerin aralarında anayasal güvenceye dayalı bir yetki paylaşımıyla oluşturdukları devlet topluluğudur. ${ }^{[53]}$ Federal devletlerde iki farklı devlet yapısı vardır ve bunlar kendi yetki alanlarında hareket ederler. Bazı konularda her federe devlete ayrı bir yetkinin verilmesi düşünülemez. Örneğin para basma konusunda yetki federal devlete aittir ve federe devletler kendi p aralarını basamazlar. Öte yandan federal devlette farklı devlet yapılarının sonucu olarak farklı hukuk düzenleri, farklı yasama organları ve farklı yürütme yapıları mevcuttur.

Devletin örgütleniş biçiminden kaynaklı özellikler vergilendirme yetkisini de etkileyebilmektedir. Bir devletin merkezi veya federal yapıya sahip olma-

[52] Nalbant, A. (1997). Üniter devlet bölgeselleşmeden küreselleşmeye, İstanbul: Yapı Kredi Yayınları, s. 44.

[53] Gözler, Devletin genel teorisi, s.143. 
sına göre vergilendirme yetkisinin kullanılması veya bölüşümü değişkenlik gösterir. Üniter devletlerde siyasal iktidar teklik gösterdiğinden vergilendirme yetkisinin bölüşümü ancak mahalli idarelerle olmaktadır. Federalizmde ise vergilendirme yetkisinin de dâhil olduğu egemenliğin içerdiği yetkiler, federal devlet ile federe devletler arasında paylaşılmaktadır. Vergilendirme yetkisinin paylaşımına ilişkin kurallar, ilke olarak bu devletlerin anayasalarında yer alır. Diğer yandan gerek federal devletlerde gerek merkezi devletlerde mahalli idarelere belirli sınırlar içinde vergi koyma, tahakkuk ve tahsil yetkileri de verilebilmektedir.

\subsection{2. Üniter Devletlerde Vergilendirme Yetkisi}

Üniter devletlerin idari teşkilatı merkezi idare ve mahalli idare olarak ayrılmakta olup merkezi idare de başkent teşkilatı ve taşra teşkilatı olarak ikiye ayrılmaktadır. Ancak üniter devletlerin merkezi idaresi başkent ve taşra teşkilatı olarak ayrılmış olsa da bir bütündür ve vergilendirme yetkisinin de dâhil olduğu bütün yetkiler esas itibarıyla başkent teşkilatında toplanmaktadır. Üniter devletin başkent ve taşra teşkilatlarının gelir ve giderleri tek bir bütçede toplanır ve buna merkezi bütçe denir. ${ }^{[54]}$ Genel olarak başkent teşkilatı vergilendirme faaliyetlerini programlamakta ve yönetmekteyken taşra teşkilatı sadece vergilerin tahsiline yönelik faaliyet yürütmektedir. Üniter devletlerde vergilendirme yetkisinin kullanımı merkezi idare ve mahalli idare düzeyinde ortaya çıkmaktadır. Buna ek olarak vergilendirme yetkisi kısmen meslek kuruluşlarına örneğin ticaret ve sanayi odalarına, borsalarına veya dinsel niteliğe haiz kilise v.b. kuruluşlarla da paylaşılabilir. ${ }^{[55]}$ Vergilendirme yetkisinin ne kadarının paylaşılacağı mahalli idarelere tanınan mali özerklikle ilgilidir. Mali özerklik merkezi yönetimce belli sınırlar dâhilinde mahalli idarelere finansal kaynakların tahsisi konusunda karar verme ve vergi toplama yetkisinin tanınmasıdır. ${ }^{[56]} \mathrm{Bu}$ yetki ile mahalli idareler yasal düzenlemeler çerçevesinde ayrı gelir kaynaklarına sahip olabilmekte ve kendi organlarının kararlarına dayanarak harcama yapabilmektedirler. Mali özerklik ülkedeki tüm hizmetlerin merkezi idarece yapılamamasının doğal bir sonucudur. Bireylerin mahalli idare hizmetlerine ihtiyaç duyması ve bu hizmetlerin finansmanı sorunu mali özerklik fikrinin temelini oluşturmaktadır. Vergilendirme yetkisinin hangi

[54] Özyörük, M. (1977). İdare hukuku ders notları, Teksir, Ankara, s. 32.

[55] Çağan, a.g.e., s. 8.

[56] Boschmann, N. Fiscal decentralization and options for donor harmonisation. http:// www.delog.org/cms/upload/pdf/Fiscal Decentralisation.pdf aktaran Egeli, H., Diril, F. (2012). Türkiye'de yerel yönetimlerde mali özerklik ve vergilendirme yetkisi. Sayıştay Dergisi, (84) s. 27. 
ölçüde mahalli idarelere bırakılacağı sorunu mali özerkliğin ölçüsüne göre cevaplandırılabilir. Vergilendirme yetkisini egemenlik gücüne dayanarak kullanan merkezi idare bu yetkiyi mahalli idarelere devrettiği ölçüde mali özerkliğin boyutları değişebilmekte ve vergilendirme yetkisi-mali özerklik ilişkisinin önemi de bu noktada ortaya çıkmaktadır. Bu ölçü merkezi idarenin güçlülük derecesine göre değişiklik arz etmektedir. Merkezi idarenin güçlü olduğu İngiltere ve Fransa gibi ülkelerde vergilendirmeyetkisi büyük ölçüde merkezi idarece kullanılmaktadır. ${ }^{[57]}$

Üniter devletlerde vergilendirme yetkisi doğal olarak merkezi yönetime aittir. Üniter devletlerde mahalli idarelere tanınacak vergilendirme yetkisi genel olarak yasa ile belirlenmektedir. Örneğin ülkemizde 2464 sayılı Belediye Gelirleri Kanununda mahalli idare olan belediyece görülecek olan hizmetlerin finansmanı maksadıyla katılma payı adı altında istenebilecek bedeller öngörülmüsstür. ${ }^{[58]}$ Yerel nitelikli vergilerin ve harçların oranlarının belirlenmesinde mahalli idarelerin yetkileri sınırlıdır ve benzer şekilde yasalarca çizilen çerçevede kullanılabilir. Aynı yasada hizmet karşılığı alınacak ücretlerin belirlenmesinde belediye meclislerine tarife düzenleme yetkisi verilmiştir. ${ }^{[59]}$

[57] Arıkan, a.g.t., s.18.

[58] Örneğin 2464 Sayılı Belediye Gelirleri Kanunu Yol Harcamalarına Katılma Payı: Madde 86 - (Değişik Birinci Cümle: 12/11/2012-6360/28. madde) Belediyelerce veya belediyelere bağlı müesseselerce

[59] 2464 Sayılı Belediye Gelirleri Kanunu Ücrete Tabi İşler: Madde 97 (Değişik: 4/12/1985 3239/125. madde.) Belediyeler bu kanunda harç veya katılma payı konusu yapılmayan ve ilgililerin isteğine bağlı olarak ıfa edecekleri her türlü hizmet (...) (1) için belediye meclislerince düzenlenecek tarifelere göre ücret almaya yetkilidir. Belediye’ye tekel olarak verilmiş işler kendi özel hüküml erine tabidir. 
Çizelge 2.1. Mahalli İdarelerin Gelirlerinin Mali Özerklik Açısından Sıralanış ${ }^{[60]}$

\begin{tabular}{|c|c|c|c|}
\hline & $\begin{array}{l}\text { Yüksek } \\
\text { mahalli }\end{array}$ & Yerel vergiler & $\begin{array}{l}\text { Verginin oran ve matrahı yerel } \\
\text { yönetimlerin kontrolündedir. }\end{array}$ \\
\hline & özerklik & $\begin{array}{l}\text { Ek vergi ve ek } \\
\text { oran yoluyla } \\
\text { sağlanan } \\
\text { gelirler }\end{array}$ & $\begin{array}{l}\text { Verginin matrahı merkezi yö- } \\
\text { netim tarafindan belirlenirken, } \\
\text { oranı yerel yönetimlerin kontro- } \\
\text { lü altındadır. }\end{array}$ \\
\hline & & $\begin{array}{l}\text { Vergi dışı } \\
\text { gelirler }\end{array}$ & $\begin{array}{l}\text { Hizmet karşılığında alınacak } \\
\text { ücretin tutarını yerel yönetimler } \\
\text { belirlemektedir. }\end{array}$ \\
\hline & & $\begin{array}{l}\text { Paylaşılan } \\
\text { vergiler }\end{array}$ & $\begin{array}{l}\text { Verginin matrahı ve oranı mer- } \\
\text { kezi yönetim tarafından belir- } \\
\text { lenmektedir. Ancak, paylaşımda } \\
\text { uygulanan yönteme bağlı olarak } \\
\text { yerel yönetimler mali kapasitele- } \\
\text { rinin artırarak paylaşım sonrası } \\
\text { alacakları payı etkileyebil ine } \\
\text { olanağına sahiptir. }\end{array}$ \\
\hline & & $\begin{array}{l}\text { Genel amaçlı } \\
\text { yardımlar }\end{array}$ & $\begin{array}{l}\text { Genel amaçlı yardımlar, merke- } \\
\text { zi yönetim tarafından herhangi } \\
\text { bir koşula bağlı olmaksızın ya- } \\
\text { pılmaktadır. Bu tip yardımlarda } \\
\text { yerel yönetimler yardımları her- } \\
\text { hangi bir kısıtlama olmaksızın } \\
\text { serbestçe harcayabilmektedir. }\end{array}$ \\
\hline $\begin{array}{l}\text { Düşük } \\
\text { mahalli } \\
\text { özerklik }\end{array}$ & & $\begin{array}{l}\text { Özel amaçı } \\
\text { yardımlar }\end{array}$ & $\begin{array}{l}\text { Merkezi yönetim tarafından ye- } \\
\text { rel yönetimlerin yaptıkları belir- } \\
\text { li harcamalarla orantılı olarak ya } \\
\text { da belirli amaçların gerçeklessti- } \\
\text { rilmesi amaçyla verilmektedir. } \\
\text { Özel amaçlı yardımlarda, para- } \\
\text { nın nereye harcanacağ merkezi } \\
\text { yönetim tarafından belirlen- } \\
\text { mektedir. }\end{array}$ \\
\hline
\end{tabular}

[60] Ulusoy, A., Akdemir, T. (2009). Yerel yönetimler ve mali özerklik:Türkiye ve OECD ülkelerinin karşılaştırmalı analizi, Balıkesir Üniversitesi Sosyal Bilimler Enstitüsü Dergisi, 12(21), s. 268. 
Çizelge 2.2. Mali Özerkleşme ve Yönetimler Arası Vergilendirme Yetkisinin Kullanımı

\begin{tabular}{|l|l|}
\hline $\begin{array}{l}\text { Mali Özerkliğin } \\
\text { Aşamaları }\end{array}$ & \multicolumn{1}{c|}{ Vergilendirme Yetkisinin Aşamaları } \\
\hline $\begin{array}{l}\text { Geniş Mali } \\
\text { Özerklik }\end{array}$ & $\begin{array}{l}\text { Yerel yönetimlere belirli vergi alanları tanınmakta ve } \\
\text { bırakilmaktadır. Yerel yönetimlerin ilgili organları } \\
\text { bu vergilerin konularını, yükümlülerini, matrahları- } \\
\text { nı, oranlarını ve diğer koşullarım belirleme yetkisine } \\
\text { sahiptir. Vergilendirme yetkisinin en geniş şekliyle } \\
\text { yerel yönetimler tarafından kullanıldığı bir aşama } \\
\text { olarak görülebilir. }\end{array}$ \\
\hline $\begin{array}{l}\text { Sınırlı Mali } \\
\text { Özerklik }\end{array}$ & $\begin{array}{l}\text { Vergilendirme yetkisi sınırlı ölçüde yerel yönetim- } \\
\text { lere devredilmektedir. Yasama yetkisinin yerel yö- } \\
\text { netimlere devrinin olmadı̆ğ sadece yerel yönetim- } \\
\text { lere tahsisi uygun görülen bir kısım vergilerin tarh, } \\
\text { tahakkuk ve tahsil yetkisinin devrini ifade eden bir } \\
\text { yöntemdir. Ayrıca, merkezin belirlediği belirli sınır- } \\
\text { lar dâhilinde vergi oranlarının belirlenmesi şeklinde } \\
\text { devri tanınabilmektedir. }\end{array}$ \\
\hline $\begin{array}{l}\text { Merkeze } \\
\text { Bağlılık }\end{array}$ & $\begin{array}{l}\text { Tarh ve tahsil yetkisinin tamamen merkezi devlet ta- } \\
\text { rafından kullanıldı̆̆ı yerel yönetimlere ancak, elde } \\
\text { edilen vergilerden, çeşitli ölçütlere göre pay aktarılan } \\
\text { bir aşamadır. }\end{array}$ \\
\hline
\end{tabular}

Çizelgede ülkede mali özerkliğin hangi düzeyde olduğu ve vergilendirme yetkisinin kullanımının hangi düzeyde olduğu gösterilmiştir.

Geniş mali özerklik, mahalli idarelere vergilendirme kapsamında konular oluşturma, bunların matrahlarını, vergi oranlarını ve diğer koşulları belirleme hakkı verilmesi, diğer bir anlatımla bağımsız bir vergileme yetkisi alanı bırakılması anlamına gelir. Geniş mali özerklikte mahalli idareler hiçbir kısıtlamaya tabi tutulmaksızın tam bir vergilendirme yetkisine sahiptirler. Bağımsız vergilendirme yetkisinden anlaşılması gereken, mahalli idarelerin kendi başına vergi oluşturabilmesi, bu verginin oranını belirleyebilmesi ve nihayet vergiyi tahsil edebilmesidir. ${ }^{[61]}$ Geniş mali özerkliğin avantajları ve dezavantajları vardır. Geniş mali özerklik, mahalli idarelere yerel ihtiyaçların daha iyi gözlemlenmesi ve yerine getirilmesi için finansman yaratma olanağı sunmakla birlikte vergilendirme sisteminin birliğini bozmakta, farklı gelişmişlik düzeylerine sahip mahalli idareler oluşmasına yol açabilmektedir. Her halükârda merkezi

[61] Egeli, H., Diril, F. (2012). Türkiye'de yerel yönetimlerde mali özerklik ve vergilendirme yetkisi. Sayıstay Dergisi, (84), s. 31. 
idarenin genel bir denetleme yetkisi vardır. ${ }^{[62]}$

Sınırlı mali özerklikte ise, devletin vergilendirme konusundaki yasama yetkisi mahalli idarelere devredilmez, diğer bir anlatımla, mahalli idareler yeni bir vergi konusu yaratamazlar, sadece bazı vergilerin tarh, tahakkuk ve tahsil yetkisine sahip olurlar. Bu yöntemin vergi gelirlerinin ağırlıklı olarak merkezi yönetimin elinde toplanmasına yol açtığı, mahalli idarelere ise sınırlı ölçüde bazı yerel vergiler ve harçların tahsil yetkisi bıraktığı, bunun sonucunda mahalli idarelerin merkeze olan bağımlılıklarının arttığı iddia edilmiştir. Mahalli idarelerin merkezi idarenin müdahalesinden uzak faaliyette bulunmalarının oldukça güç olması, etkin kaynak kullanımı bakımından yetersiz kalınması ve bölgesel olarak farklılaşan hizmetlerin yerine getirilmesinin güçleşmesi, bu yöntemin zayıf noktalarını oluşturmaktadır. ${ }^{[63]}$

Merkeze bağlllık yönteminde, vergilendirme yetkisi merkezi yönetime aittir. Vergi koyma ve vergilemeye ilişkin diğer hususların merkezi yönetim tarafından belirlendiği bu yöntemde nüfus, ulusal gelirden aldıkları pay gibi çeşitli kriterlere göre yerel yönetimlere pay verilmektedir. Tamamen merkeze bağlı bir kaynak kullanımı söz konusu olduğundan mali özerklik sağlanamamaktadır. ${ }^{[64]}$

Mahalli idarelere vergilendirme yetkisinin devri, özellikle bina, arazi ve arsa vergileri gibi yerel özelliği daha belirgin olan vergilerin mahalli idarelerin yetki alanları içinde bırakılması, demokratik devlet ilkesine daha uygundur. Mahalli hizmetlerin mahalli sınırlar içinde bulunan taşınmazlarla yakın ilişkisi olması, bu durumu doğrulamaktadır. Gelişmiş demokrasilerde söz konusu vergilerin mahalli idarelerin yetkisine bırakıldığı görülmektedir. ${ }^{[5]}$ Örneğin Fransız Anayasası'nda mahalli idarelerin yasayla belirlenen şartlar çerçevesinde, serbestçe tasarruf edebilecekleri gelirlere sahip olduğu, her türlü vergi gelirlerinin tamamını veya bir kısmını alabilecekleri, vergi yasalarının belirlediği sınırlar içinde, mahalli idarelere, vergilerin matrah ve oranının tespitine yasayla izin verilebileceği, vergi gelirlerinin ve öz kaynakların, her yerel yönetim kategorisi için, gelirlerinin tamamı içinde önemli bir bölümünü teşkil edeceği, bu kuralın gerçekleştirilmesi koşullarının ise bir yasayla belirleneceği ifade edilmiştir. (Any. 72-2/1, 2, 3) Benzer bir hükümde 1982 Anayasası'nda yer almakta, mahalli idarelere görevleri ile orantılı gelir kaynakları sağlanacağı hükme bağlanmıştır. Ancak Anayasada da bu gelirlerin hangi kaynaklardan

[62] Öncel, Çağan, Kumrulu, a.g.e., s. 44.

[63] Egeli, Diril, a.g.m., s. 32.

[64] Öncel, Çağan, Kumrulu, a.g.e., s. 44.

[65] Öncel, Çağan, Kumrulu, a.g.e., s. 45. 
ve nasıl sağlanacağı ve nasıl güvence altına alınacağı belirtilmemiştir. ${ }^{[66]}$ Salt madde metninden hareketle mahalli idarelere hangi oranda vergilendirme yetkisinin devredildiğine ilişkin bir sonuca ulaşılması zordur. Türkiye’de mali özerkliğin niteliği ancak yasaların yorumlanması ile anlaşılabilir.

Vergilendirme yetkisinin mahalli idarelere devri konusunda uygulamada en çok karşılaşılan yöntem, vergi matrahının merkezi idarece belirlendiği, buna karşılık, vergi oranını belirlemede mahalli idarelere serbestliğin tanındığı sistemdir. Özellikle, Belçika, Danimarka, Hollanda, İngiltere İsveç, İsviçre gibi ülkelerde uygulanan bu sistemde, mahalli idareler genellikle merkezi idarenin belirlediği sınırlar çerçevesinde vergi oranlarını belirlemekte ve bu oranların dışına çıkamamaktadır. Vergi oranlarını mahalli idarelerin belirlediği bu yöntemin yanı sıra, Avusturya, Belçika, İspanya ve Portekiz'de mahalli idarelere vergi matrahını belirleme konusunda da önemli serbesti tanındığı görülmektedir. ${ }^{[67]}$

Vergilendirme yetkisinin mahalli idarelere devri ve mahalli idarelerin mali özerliğinden bahsedilirken Avrupa Mahalli Yönetimler Özerklik Şartı’na değinmek yerinde olacaktır. Avrupa Mahalli Yönetimler Özerklik Şartı'nda, özerk mahalli yönetimler ilkesinin ulusal mevzuatla ve uygun olduğu durumlarda anayasa ile tanınacağı (m.2), özerk mahalli yönetim kavramının, mahalli makamların, kanunlarla belirtilen sınırlar çerçevesinde, kamu işlerinin önemli bir bölümünü kendi sorumlulukları altın da ve yerel nüfusun çıkarları doğrultusunda düzenleme ve yönetme hakkı ve imkânı anlamını taşıdığı (m.3) hükme bağlanmıştır. Bu hükümlerin amacının ise bireylere en yakın birim olan mahalli idarelerin haklarına ilişkin bir Avrupa standardı oluşturmak ve yu rttaşa günlük yaşam çevresini etkileyen karar süreçlerine etkin katılma olanağını sağlamak olduğu ifade edilmiştir. Mali özerliği açıklayan 9.madde de, mahalli idarelere yeterli mali kaynakların sağlanması, mali kaynakların anayasa ve kanunla belirlenen so rumlulukla orantılı olması ve mali kaynakların en azından bir kısmının, kanuni sınırlar içinde, mahalli olarak belirlenen vergilerden karşılanması esası getirilmiştir. Maddenin 3. Fıkrasında "Mahalli idarelerin malî kaynaklarının en azından bir bölümü oran larını kanunun koyduğu sınırlar dâhilinde kendilerinin belirleyebilecekleri mahalli ve vergi ve harçlardan sağlanacaktır” hükmü yer almıştır. Maddenin gerekçesinde verilen hizmetlerden sağlanan fayda ile bunun mahalli vergi mükellefine veya kullanıcrya getireceği maliyeti belirleme konusundaki politik tercih, mahalli seçilmiş temsilcilerin temel görevidir. Merkezi veya bölgesel kanunların, mahalli ida-

[66] Öncel, Çağan, Kumrulu, a.g.e., s.45.

[67] Ulusoy, Akdemir, a.g.m., s. 274. 
relerin vergilendirme yetkisinin genel sınırlarını belirlemesi kabul edilmiştir; ancak bu kanunlar, mahalli sorumlulukların etkin biçimde gerçekleştirilmesini önleyici mahiyette olmamalıdır." ${ }^{[68]}$

Avrupa Mahalli Özerklik Şartı'nın getirdiği ölçüler bağlamında, ülkemizde, merkezi idareden aktarılan payların düşük olduğundan mahalli idarelerin gelir kaynakları bakımından yetersiz olduğundan, mahalli idarelerin gelir paylaşımı konusunda çok sınırlı imkânlara sahip olduğu görülmektedir. Örneklemek gerekirse, tahsil yetkisi mahalli idarelere bırakılmış emlak vergisinin belediye toplam geliri içindeki payı ancak \% $4-5$ arasındadır. Bu durumdan hareketle, ülkemizdeki uygulamanın pay dağıtım ilkesi olduğu ve ülkemizde Avrupa Yerel Özerklik Şartı'nda belirtilen yerellik ilkesine yeterince uyulmadığı sonucu çıkarılabilir. ${ }^{[69]}$

Üniter devlet yapısına sahip ülkeler açısından mahalli idarelere vergilendirme yetkisi devredilirken, saydamlık ve hesap verilebilirlik ilkelerine bağlı kalınması gerekmektedir. Bunun yanında mali gücün kullanımının merkezin kontrol ve denetimine bırakılması vergilendirme yetkisinin devri için öncelikli koşullardan birisidir. Bunun için idari yapıyı bozmayacak nitelikte mali özerkliğin sağlanması ve üniter yapının korunmasına yönelik tedbirlerin alınması gerekmektedir. ${ }^{[70]}$

\subsubsection{Federal Devletlerde Vergilendirme Yetkisi}

\subsubsection{Genel Olarak}

Federal devletlerde devlet fonksiyonları, üniter devletten farklı olarak, tek bir merkezde toplanmayıp, federal devlet ve federe devlet idareleri arasında bölüştürülür. Federe devletlerin yetki alanı, ülkenin belirli bölgeleri veya yurttaşların belirli bir kısmı ile sınırlıdır. ${ }^{[71]}$ Federe devlet içinde yaşayanların iki tür vatandaşlığı vardır. Bunlar hem bir federe devletin, hem de federal devletin vatandaşlarıdır. Devlet egemenliğinin içte kullanılması, federe devletlerle, federal devlet arasında bölüşülmüştür. Klasik egemenlik teorisine göre ege-

[68] Yaltı, B. (2010). Anayasa mimarisinde bir yapıtaşı; mahalli idarelerin vergilendirme yetkisi üzerine değerlendirmeler, Vergi Sorunları Dergisi, (261), s. 7-17, s. 8.

[69] Güler, B. A. (2005). Avrupa ve yerel yönetimlerin anayasal konumu Avrupa bölgesel ve yerel kongresinin değişikliği istekleri, Genel- iş Emek Araştırma Dergisi, (1), Ankara, s. 39-40. aktaran Egeli, Diril, a.g.m., s. 37.

[70] Egeli, Diril, a.g.m., s. 29.

[71] Uygun, O. (2001). Ulusüstü siyasal birlikler ve küreselleşme, küreselleşme ve ulus devlet. (Der. M. Koray), İstanbul: Y.T.Ü. Stratejik Araştırmalar Merkezi Yayını, s. 151178. 
menlik bölünemezken, federalizmde bölünmüş bir egemenliğin varlığı söz konusudur. ${ }^{[72]}$ Federal organların kendi yetki sahasında aldıkları kararlar, federe devletlerde geçerlidir ve doğrudan doğruya uygulanma kabiliyetine sahiptir. Dış egemenliğin kullanılması ise, federal devlete aittir. ${ }^{[73]}$ Federal devlette, bütün federe devletler hukuki bakımdan bir birine eşit ve bağımsız siyasal birimlerdir. Sahip oldukları yetkiler birbirine diğerine aktarılmaz. Federe devletler, bir başka ve daha üstün olan bir devletin yetki aktarımı sonucu ortaya çıkmış değildirler. Aynı özellik, ulusal ölçekte kurulan federal yönetim için de geçerlidir. Federal siyasal sistemin kendisi, yetkilerin çok sayıda iktidar merkezi arasında bölünmesinin kabul edilmesi ile ortaya çıkmıştır. ${ }^{[74]}$ Federal devlet ile federe devletler arasında yapılmış yetki paylaşımında bu devletlere güvence verilmiştir. Bu güvencenin sağlanması için yetki paylaşımının anayasayla yapılmış olması,anayasanın değiştirilmesine federe devletlerin katılabilmesi ve federe devletler ile federal devlet arasında çıkabilecek yetki uyuşmazlıklarının yargısal çözümünün öngörülmüş olması gereklidir. Federal devlet ile federe devletler arasında bağ anayasal nitelikte olduğu için bir federe devletin federasyondan ayrilma hakkı hukuken yoktur. ${ }^{[75]}$

Federasyonlarda federal devletin hukuk düzeni ve federe devletlerin kendi hukuk düzenleri olmak üzere iki ayrı hukuk düzeninden bahsedilebilmektedir. Federal hukuk düzeni federal sınırlar içinde diğer bir anlatımla bütün federe devletlerin sınırlarım kapsar biçimde uygulanır. Örneğin Boston şehrinde yaşayan bir vatandaş bu şehrin bağlı olduğu Massachuchets eyaletinin hukuk düzeni tabi olmakla beraber tüm A.B.D. federal anayasasına ve kanunlarına da tabidir.

Federalizmde federal hukukla federe hukukun çatışma durumunda federal hukukun federe hukuka üstünlüğü ilkesi geçerlidir. Örneğin Federal Almanya Cumhuriyeti Anayasası'nda federe devletlerin anayasalarının federal Anayasada belirlenen cumhuriyetçi, demokratik ve sosyal hukuk devleti ilkelerine uygun olmak zorunda olduğu ifade edilmiştir. ${ }^{[76]}$ Federal hukukun bir federe

[72] Gözler, Anayasa hukukunun genel teorisi, s. 161.

[73] Gözübüyük, A. Ş. (2007). Anayasa hukuku anayasa metni ve 11. protokole göre hazırlanmış Avrupa insan hakları sözleşmesi. (15. Bası), Ankara: Turhan Kitabevi Yayınları, s.21.

[74] Uygun, O. (1996). Federal devlet: Temel ilkeler, kurumlar ve uygulama. İstanbul: Çınar Yayınları, s.163 166.

[75] Gözler, Devletin genel teorisi, s.143.

[76] Basic law for the federal republic of Germany, (Çev. Christian Tomuschat, David, P.), Currie, Service of the German Bundestag, https://w ww.btg bestellservice.de/ pdf/80201000.pdf (İ. T. 4.3.2014). 
devlette uygulanabilmesi için ayrıca federe devletin bu hukuku kendi iç hukukuna aktarmasına gerek olmayıp doğrudan uygulanabilir niteliktedir. Ancak federal devlet hukukun üstünlüğünün geçerli olabilmesi düzenleme konusunun federal anayasayla federal devletin yetkialanına bırakılmış olmasına bağlidır. ${ }^{[77]}$

Federalizmde vergilendirme yetkisinin kime ait olacağı hususunda federal ve federe devletler arasındaki yetkiye ilişkin değerlendirmeler öncelikle geçerlidir. Bu bağlamda federal devletin vergilendirme yetkisi federe devlet ülkesi ve milletini kapsayan tüm ülke üzerinde geçerlidir. Federe devletin vergilendirme yetkisini kullanabileceği alan ise ancak federe devlet ülkesi ve milletidir. Aynı örnekten hareketle Boston şehrinde yaşayan bir A.B.D. Federal Devleti vatandaşı federal devletin yetkili kıldığı alanlarda federal devletin mükellefi olarak onun koyduğu düzenlemelere göre hareket etmek zorundadır. Diğer yandan aynı kişi Massachuchets federe devletinin vergilendirme yetkisinin de muhatabıdır. Daha da somutlaştıracak olursak alkollü içkiler ve tütün vergisi dışındaki satış vergileri genellikle eyaletler ve mahalli yönetimlerce tahsil edilmektedir. Diğer bir deyişle A.B.D.'de harcamalardan alınan satış vergisi oranının belirlenmesi ve tahsili federe devletlerin yetki alanına bırakılmıştır. Her eyalet ayrı bir satış vergisi oranı tespit edebilmektedir. Bazı eyaletlerde satış vergisi hiç alınmamaktadır. ${ }^{[78]}$ Örneğin Massachuchets federe devletinde satış vergisi oranı $\% 6$ olup bu eyaletin yetki sınırında yapılan sayışlardan bu oranda satış vergisi tahsil edilmekte, satış vergisi oranı $\% 0$ olan New Hampshire federe devletinde aynı satıştan hiç vergi alınmamaktadır. Ancak federal devletçe belirlenen kişisel gelir vergisi her federe devlette yaşayan A.B.D. vatandaşı için geçerlidir ve her vatandaş yaşadığı federe devlete bağlı olmaksızın bu verginin mükellefidir. Buna ek olarak her federe devlette federal devletin tahsil ettiği gelir vergisine benzer vergi ihdas etmeye, oranlarını belirlemeye ve tahsil etmeye kısacası vergilendirmeye yetkisi vardır. Federal ve federe devletlerin vergilendirme yetkisini genel olarak açıkladıktan ve bu yetkilerini kapsamını örneklendirdikten sonra federal ve federe devletlerin vergilendirme yetkisini münhasiran ele alabiliriz.

\subsubsection{Federal Devlette Vergilendirme Yetkisi}

Federalizmde federal devletin ve federe devletlerin varllğından ve üst üste geçen iki hukuk üzeninden bahsetmiştik. Federal hukukun federe hukuka üstünlüğ̈̈ ilkesi gereği federal devletin vergilendirme yetkisinin de federe

[77] Gözler, Devletin genel teorisi, s. 167.

[78] Demir, İ. C. (2008). A.B.D. vergi sistemi ve gelir idaresi, Afyon Kocatepe Üniversitesi, İktisadi ve İdari Bilimler Fakültesi Dergisi, X(I), s. 283. 
devletin vergilendirme yetkisine üstün olduğu sonucuna ulaşabiliriz. Ayrıca federal devletin vergilendirme yetkisinin tüm ülke ve millet üzerinde uygulanabilirliği bulunmaktadır. Ancak federal devletin vergilendirme yetkisinin sınırsız uygulanabilirliği pratikte söz konusu olamaz. Federe devletlerin federal yasama organına devlet olarak katılma ilkesi gereği, federal devletin vergilendirme yetkisini kullanacak yasama organları iki meclisli şekilde federe devletlerin katılımı ile oluşturulmaktadır. ${ }^{[79]}$ Örneğin Almanya'da yasama organı iki meclisli bir biçimde oluşmuştur ve Bundesrat federe devletleri temsil eden meclistir. Federe devletler ve federal devlet arasında vergilendirme yetkisinin kullanımına yönelikkanunlar yapılma sürecinde iki meclisin yetkileri arasında eşitlik vardır. Bu nedenle federe devletleri ve vatandaşlarını ciddi anlamda etkileyebilecek düzenlemelerin ve uygulamaların hayata geçmesi pratik açıdan zordur. Sonuç olarak federal devlette vergilendirme yetkisi federe devletleri ve vatandaşlarını zor duruma sokmayacak biçimde, dengeli ve katılımcı yollarla kullanılabilecektir.

Bazı vergilerin niteliği gereği federal devletin yetki alanında olması gerekmektedir. Federal devlet dış egemenlik açısından tek yetkili olduğundan federal devlete giren ürünlerden kaynaklı gümrük vergilerinin federal devletin yetki alanında olması gerektiği açıktır. Federal devlet uygulamalarının da bu yönde oluştuğu gözlemlenmektedir. Örneğin A.B.D.'de dış ticaretten alınan gümrük vergilerini sadece federal devlet tahsil edebilir. ${ }^{[00]}$ Bunun yanında bazı vergilerde niteliği gereği sadece federe devletlerce alınmaktadır. Örneğin emlak vergileri niteliği gereği taşınmazın bulunduğu federe devlet tarafından tahsil edilmektedir.

Federalizmin de federe devletlerin birbirleri ile sınırları yapay niteliktedir ve insan ve mal hareketi sınırlandırılmamıştır. Bu nedenle bir federe devlette mukim özel veya tüzel kişilerin farklı federe devletler bünyesinde gelir elde etmesi mümkündür ve çoğunlukla gerçekleşmektedir. Bu noktada kişisel gelirin veya kurum gelirinin bir federe devletçe vergilendirilmesi ve o federe devlete aktarımı mümkün olmayacaktır. Farklı federe devletlerce birden çok kez vergilendirilmesi ise son derece karmaşık olacak ve pratik olarak mümkün olmayacaktır. Bir federe devletin diğer federe devletlerin yetki alanına müdahale edememesi, oradaki gelir hakkında bilgi sahibi olmasının güç olması, ${ }^{[81]}$ onları denetleme yetkisi olmaması ve gelirin hangi kısmının hangi oranda hangi fe-

[79] Gözler, Devletin genel teorisi, s. 154.

[80] Demir, a.g.m., s. 281.

[81] Buchanan, J. M., Flowers, M. R. (1987). The publicfinance, Sixth Edition, s. 324325 aktaran, Arıkan, a.g.t., s. 14 . 
dere devletçe belirleneceği hususunda karmaşa çıkacak olması bu sonucu dogurmaktadır. Bu nedenle kişisel gelirin veya kurum gelirinin federe devletlerce değil federal devlet tarafından vergilendirilmesi gerekecektir. Federalizmin geçerli olduğu ülkelerde genel uygulama da benzer yöndedir. Ancak bu yaklaşım federe devletlerin ek olarak kişisel geliri veya kurum gelirini vergilendirmesine engel değildir.

Kişisel gelirin veya kurum gelirin vergilendirilmesinde vergilendirme yetkisinin federal devlete ait olmasının diğer bir nedeni de bu vergilerin diğer vergilere nazaran idari maliyetlerinin yüksek oluşundan kaynaklanmaktadır. Çünkü bu gelirlere ilişkin vergilerin tahakkuku, tahsili ve denetlenmesi çok sayıda personel ve teçhizat gerektirir. Bu durumun ortaya çıkardığı yüksek maliyet göz önünde bulundurulduğunda bu maliyetin merkezi bir yapı niteliğinde olan federal devletçe organize edilmesi daha etkili ve yerinde olacaktır. ${ }^{[82]}$

Federal devletçe kullanılacak vergilendirme yetkisinin federe devletleri ve vatandaşlarını etkileyeceği açıktır. Çünkü federal devletin ülkesi federe devletler ülkesinin tamamı vatandaşları, federe devlet vatandaşlarının tamamıdır. Federalizmin niteliği gereği federe devletlerle federal devlet arasındaki vergilendirme yetkisinin bölüşümünün ihlal edilmesi durumunda bunu engelleyecek müesseselerin ihdası gerekir. Aksi halde federal devletin yetki alanını ihlal etmesi her zaman muhtemeldir. Bu nedenle federal devletin ve federe devletlerin, kendi onaylarıyla ortaya çıkan anayasaya uygun davranmaları gerekir. Ortaya çıkacak yetki uyuşmazlıklarının, yetkili organlarca genellikle yargı organıdır çözümlenmesi gerekmektedir.

\subsubsection{Federe Devletlerde Vergilendirme Yetkisi}

Federalizmin hukuki niteliği gereği egemenliğin içerdiği yetkilerin, federal devlet ile federe devletler ve mahalli idareler arasında paylaşılarak kullanılması gerekir. Vergilendirme yetkisi bakımından da aynı paylaşım söz konusu olmaktadır. Yetki paylaşımına ilişkin kurallar, ilke olarak bu devletlerin anayasalarında yer alır. Öte yandan gerek federal devletlerde gerek merkezi devletlerde mahalli idarelere belirli sınırlar içinde vergi koyma veya tarh, tahakkuk ve tahsil yetkileri verilmiştir. ${ }^{[83]}$

Diğer yandan federalizmde her federe devlete münhasır bir egemenlik alanı tanınmaktadır. Federe devletler anayasa ile belirlenmiş konularda ve sınırlarda, kendi ülkesi ile kendi vatandaşları üzerinde vergilendirme yetkisine,

[82] Musgrave, R. A., Musgrave, P. B. Public finance in theory andpractice, Fifth Edition, Mc. Graw Hill Book Company, ss. 203 aktaran Arıkan, a.g.t., s. 14.

[83] Çağan, a.g.e., s. 57. 
dolayısıyla mali egemenliğe sahiptirler. Bununla birlikte aynı ülke ve insanlar üzerinde federal devletin de aynı yetkiye sahip olduğu açıktır. Buradan harekete aynı alanda yetki kullanabilecek olan egemenliklerin çatışması söz konusu olabilir. Böyle bir çatışmanın oluşmaması için yetki alanlarının netleştirilmesi gerekmektedir. Bu da ancak devletlerin vergilendirme yetkilerinin anayasayla belirlenmesi ile mümkündür.

Vergilendirme yetkilerinin belirlenmesinde farklı usuller getirilmiştir. En fazla uygulanan yönteme göre federal devletin yetkileri tek tek sayılır ve sayılan yetkiler dışında kalan yetkilerin federe devletlere ait olduğu varsayılır. İkinci sistemde anayasada federe devletlerin yetkileri tek tek sayılır, bu yetkiler dışında kalan yetkilerin federal devlete ait olduğu varsayılır. Son olarak bazı anayasalarda federal devletin münhasır yetkisi olduğu belirtildikten sonra diğer alanlarda hem federal hem de federe devletlerin yetkili olduğu ifade edilebilir. ${ }^{[84]}$ Federe devletler ile federal devlet arasında yetki paylaşımına ilişkin bu yöntemler vergilendirme yetkisi için de geçerlidir. Örneğin İsviçre Anayasası, kantonların yani federe devletlerin ancak anayasanın açı bir biçimde federal devlete bıraktıklarının dışında kalan vergileri tarh ve tahsil edebilme yetkisine sahip olduğunu ifade etmiştir. ${ }^{[85]}$

Vergilendirme yetkisinin kullanım alanı farklı vergiler olabileceğinden vergi türlerine göre yetkilendirme ayrı bir yöntem olarak kullanılmaktadır. Örneğin İsviçre Anayasasında vergi türüne göre yapılmış bir ayrım bulunmaktadır. Buna göre gümrük vergileri ile damga vergisi konuları federal devletin yetki alanına bırakılmış olup kantonlar bu konular üzerinde vergilendirme yetkisine sahip değillerdir. ${ }^{[8]}$ Öte yandan benzer bir yaklaşım mahalli idareler ile federe devletler arasındaki yetki paylaşımı içinde kullanılmaktadır. Örneğin A.B.D.'de federe devletler harcama ve satış vergileri ile lisans vergisi gibi vergiler konusunda yetki sahibi iken mahalli idareler daha yerel niteliğe sahip olan emlak vergisi konusunda yetki sahibidirler. ${ }^{[87]}$

Vergilendirme yetkisi konusunda federe devletler arasındaki yetki paylaşımında mülkilik ilkesinin geçerli olduğu söylenebilir. Federe devletler kendilerine tanınan vergisel konularda yer bakımından yetkilidirler. Diğer bir anlatımla her federe devlet kendi ülkesi ve vatandaşları üzerinde yetkilidir.

[84] Gözler, Devletin genel teorisi, s. 170.

[85] Http://www. Admin.Ch/Ch/E/Rs/1/101.En.Pdf (İ.E.T. 5.3.2014)

[86] Nadaroğlu, H. (1998). Mahalli idareler teorisi ekonomisi uygulaması. İstanbul: Beta Yayınları, s. 106-107.

[87] Sharp, A. M., Sliger, B. F. (1964). Publicfinance. Ilhonis: Dorsey Press, Homewood, s. 316. aktaran Arıkan, a.g.t., s. 15. 
Federe devletler arasında konu bakımından bir uyuşmazlık çıkması mümkün olmasa da yer bakımından uyuşmazlıklar çıkabilir. Bu uyuşmazlığı çözecek organ genellikle anayasalarda gösterilmektedir. Örneğin Federal Almanya Anayasası'nın 93. maddesinin 4. fikrasında federal devlet ile federe devletler arasında veya federe devletlerin kendi aralarında veya başka bir yasa yolu bulunmadığı takdirde bir federe devlet içinde çıkan kamu hukuku uyuşmazlıkları çözüme bağlama konusunda Federal Anayasa Mahkemesi'nin yetkili olduğunu ifade etmektedir. ${ }^{[88]}$ Federe devletlerin vergilendirme yetkisini kullanırken verginin ekonomik yönünü ihmal etmemeleri gerekir. Çünkü vergilendirme yetkisinin muhatabı olan özel ve tüzel kişiler; kendisine izin verilen her konuda vergilendirmeye giden ve aşırı vergi yükleri getiren federe devletlerin yetki alanlarında yaşamaktan, gelir elde etmekten ve yatırım yapmaktan kaçınacaklardır. Bu durum ise federe devletin gelişimime mâni olacaktır. Sonuç olarak federe devletlerin vergilendirme yetkisinin hukuksal sınırlarınındın başka ekonomik sınırlarının da olduğu söylenebilir.

Federe devlet yapılanması içinde mahalli idarelere belirli sınırlar içinde vergilendirme yetkisi verilmektedir. Bu genellikle yetki paylaşımı yoluyla olmaktadır. Mahalli idareler üniter devletler de merkezi idarenin izin verdiği ölçüde bu paylaşıma katılırken federalizmde ise federal devlet ile federe devletlerin izin verdiği ölçüde bu paylaşıma katılmaktadırlar. Genelde paylaşımın ölçüsü mali özerkliğin ölçüsü ile paraleldir.

Mahalli idarelerin vergilendirme yetkisine yönelik üniter devlet başlığı altındaki özerklik ve uygulaması ile ilgili yapılan açıklamalar federalizm uygulaması içinde geçerlidir.

\subsubsection{Bölgesel Devletlerde Vergilendirme Yetkisi}

Bölgesel devlet esasında üniter bir devlettir. Bölgesel devleti üniter devletten ayıran ise özerklik verilen bölgelerin kendine has yasama meclisleri ve bazı önemli yetkilere sahip olmasıdır. ${ }^{[89]}$ Bölgesel devletlerde siyasal iktidar tektir. Bölgesel devletler federasyonların çok ülke anlayışı ile üniter devletlerin tek ülke anlayışı arasında bir yerde durmaktadır. Bölgesel devletlerde bölgeler değisik adlarla adlandırılır. İspanya’da bölgesel devletler, özerk topluluk veya yönelim, İtalyảda bölge, Portekiz'de siyasal bölge olarak adlandırılmaktadır. Buna karşılık hiçbir siyasal yetkisi olmayan ve bir yerel yönetim olan Fransız il üstü

[88] Basic law for the federal republic of Germany, Translated by Professor Christian Tomuschat and Professor David P. Currie, Https://Www.Btg-Bestellservice.De/ Pdf/80201000.Pdf (İ.E.T. 5.3.2014)

[89] Gözler, Devletin genel teorisi, s. 186. 
yönetim kademesi de bölge (region) olarak anılır. ${ }^{[0]}$ Bölgesel devletlerin neler olduğu genelikle anayasalarda yer almaktadır. Örneğin İtalyan Anayasası'nın 116. maddesinde Friuli-Venezia Giulia, Sardinia, Sicily, Trentino-Alto Adige/ Südtirol ve Valle d'Aosta/Vallee d'Aoste bölgelerinin Anayasa'nın kabul ettiği özel statülere göre özel biçim ve koşulları olan özerkliklere sahip olduğu ifade edilmiştir.

Bölgesel devletlerde merkezi devletin yasama yetkileri üzerinde hükümet denetimi veya yargısal denetimi vardır. Örneğin İtalyảda bölgelerin yasama yetkisi üzerindeki hükümet komiserinin veto yetkisi hükümet denetimi niteliğinde iken, İtalya ve İspanya'da Anayasa Mahkemesi'nin denetimi ise yargısal denetimdir. ${ }^{[91]}$

Bölgesel devletlerde özerklik güvence altına alınmakla birlikte, merkezi yönetimin özerk yönetimlerin kuruluş ve işleyişine müdahale etme imkânı vardır. Örneğin İtalya’da, merkezi yönetim kendisi tarafından verilen idari görevlerin özerk yönetimlerce yerine getirilip getirilmediğini denetleme hakkına sahiptir. Ayrıca bölgesel devletlerce kabul edilen yasalar üzerinde geciktirici veto yetkisi vardır. Merkezi yönetim, bu yasaları Anayasa Mahkemesi'ne veya ulusal parlamento önüne getirerek geçersiz sayılmasını isteyebilir. Bu ve benzeri hükümler, merkezi yönetimlerin özerk yönetimlerin üstünde bir statüye sahip olduğunu göstermektedir. Özerk yönetimler, federe birimlerden farklı olarak, kendi yetki alanlarına giren konular bakımından nihai karar verme yetkisine sahip olmadıklarından federal devletten daha az yetkilidirler denilebilir.

Bölgesel devletlerde yapı alt yönetim düzeyleri (il yönetimi ve belediyeler) orta kademe yönetim düzeyleri (bölge yönetimleri) ve merkezi yönetim olarak planlanmışır. Bölge yönetimlerinin farklı yetkileri sahip olması Anayasa'da böyle bir farklılık yaratılmasına bağlıdır. Bazı özel statülü bölge yönetimlerine belirli sınırlar çerçevesinde yasama yetkisi verilebilir. Alt yönetim düzeyleri vergilendirme yetkisi bakımından orta yönetim düzeylerine yani bölgesel devletler bağlı olmayıp sadece merkezi yönetime bağlıdırlar. ${ }^{[92]}$

Bölgesel devletlerin vergilendirmeye ilişkin yetkileri çoğunlukla anayasalarda bazende yasalarda düzenlenmektedir. Bu noktada üniter devletlerde merkezi idare mahalli idareler ile merkezi idare ilişkisinden farklılık arz etmektedir. Örneğin İtalya Anayasası sağlık, yerel, ulaşım, tarım, mesleki eği-

[90] Nalbant, a.g.e., s. 6-10.

[91] Nalbant, a.g.e., s. 15.

[92] Arslan, M., Biniş, M. (2011). İtalya Vergi sistemi ile Türk vergi sisteminin karşılaştırmalı analizi, Vergi Sorunları Dergisi, (274), sayfa no yok. 
tim kamusal görevleri merkezi idareye değil bölge yönetimlerine vermiştir. Bu konularda bölge yönetimleri anayasal sınırlar içerisinde düzenleme yapma yetkisine sahiptir. ${ }^{[93]}$ İspanya Anayasası'nda da benzer hükümler vardır. Özerk Toplulukların Mali Özerkliği başlıklı 156. maddede 'l.Özerk Topluluklar, Hazine ile koordinasyon ve tüm İspanyollar arasında birlik ilkeleriyle uyum içinde, yetkilerini geliştirmek ve uygulamak için mali özerkliğe sahiptir. 2. Özerk Topluluklar, kanun ve Statülere uygun olarak, Devletin vergi kaynaklarının toplanması, yönetimi ve tasfiyesi için Devletin temsilcisi veya işbirlikçisi olarak hareket edebilir.' hükmü yer almıştır. Bu düzenlemeler belirli kamusal amaçlar için bölgesel devletlerin vergilendirme yetkisine sahip olduğunu göstermektedir.

\subsection{Siyasi Rejimlere (Yönetim Biçimlerine) Göre Vergilendir- me Yetkisi}

\subsubsection{Genel Olarak}

Bir ülkede etkin siyasi rejim ülkedeki tüm müesseseleri etkileyerek şekillendirdiği gibi devletin vergilendirme yetkisinin niteliğini ve kullanımını da şekillendirmektedir. Bu bağlamda siyasi rejimlerin vergilendirme ve vergilendirme yetkisi üzerindeki etkilerinin açılanması yararlı olacaktır.

Siyasi rejimlerin tasnifinde ve hangi ölçülerin esas alınması gerektiği hususunda çok çeşitli yaklaşımlar bulunmaktadır. Ancak tezin amacının aşılmaması maksadıyla bu sınıflandırma siyasal iktidarın temel hak ve hürriyetlere karşı tutumuna göre yapılacaktır. Bu bağlamda siyasal iktidarın yönetilenlere kamu hürriyetlerini tanıma ölçüsüne göre yönetim biçimlerini antidemokratik ve demokratik rejimler olarak ayırabiliriz. ${ }^{[94]}$

Totaliter ve otoriter rejimler olmak üzere iki kısma ayrılan antidemokratik rejimlerde demokrasi ilkeleri genel olarak uygulanmaz. Antidemokratik rejimlerde genel olarak temel hak ve hürriyetler tanınmamakta veya keyfi olarak sınırlanabilmektedir. Genellikle ülkeyi yöneten hanedan veya partinin iktidarı süreklilik arz eder. Faşizm veya Nazizm gibi antidemokratik sistemlerde de ırk veya millet ya da halk kutsallaştırılır. ${ }^{[95]}$ Devlet iktidarını sınırlandıran metinlere rastlanmaz diğer bir anlatımla anayasacılık hareketinden bahsedilemez. ${ }^{[96]}$

[93] Arslan, Biniş, a.g.m., sayfa no yok.

[94] Derdiman, R. C. (2011). Anayasa hukuku. (2. Baskı), İstanbul: Alfa Aktüel Yayınlar1, s. 93.

[95] Tunaya, T. Z. (1975). Siyasi müesseseler ve anayasa hukuku. (3. Bas1), İstanbul: Sulhi Garan Matbaası Koll. Şti., s. 652.

[96] R. Cengiz Derdiman, a.g.e., s. 94-95. 
Demokrasi ve vergilendirme yetkisi başlığında ayrıntılı açıklandığı üzere demokratik reji mler; karar verici siyasal makamların çok partili, belli aralıklarla tekrarlanan ve muhalif partilerin de iktidar olma şansına sahip olduğu ve temel hak ve hürriyetlerin anayasa ile tanındığ 1 ve güvence altına alındığı rejimler olarak tanımlanabilir. ${ }^{[97]}$ Demokratik rejimlerde antidemokratik rejimlerin aksine temel hak ve özgürlükler anayasal metinlere güvence altına alınmıştır. Serbest seçimler yoluyla muhaliflere iktidar oma şansı verilmiştir. Bu anlamda etkin siyasal makamlar sürekli bir biçimde hanedan veya bir parti tarafından kullanılmaz. Herhangi bir zümreye ve ırka üstünlük atfeden uygulamalara rastlanılmaz. Devlet iktidarı sınırlıdır ve yönetenler kendi koyduğu kurallara kendileri de bağlıdır.

Hem antidemokratik rejimlerin hem de demokratik rejimlerin genel ilke ve uygulamalarının vergilendirme yetkisinin nitelik ve kullanımım etkilediği görülmektedir.

\subsubsection{Antidemokratik Rejimlerde Vergilendirme Yetkisi}

Antidemokratik rejimlerde anayasa yoktur veya var olan anayasa iktidar sahiplerini sınırlayıcı olmaktan çok onlar tarafından araç olarak kullanılmaktadır. Bu bağlamda antidemokratik rejimlerde genelde egemenliğin özelde mali egemenliğin içte sınırsız kullanımı söz konusudur. Vergilendirme yetkisi mali egemenliğin bir yönünü teşkil ettiğinden onun da sınırsız kullanımı söz konusu olmaktadır.

Anayasa düşüncesinin olmadığı rejimlerde devletin vergilendirme yetkisini kötüye kullanması ve suiistimal etmesi her zaman söz konusu olabilir. Çünkü bu rejimlerde bireyler devletin vergilendirme yetkisini ne şekilde kullanabileceğine ilişkin ilkeleri ve vergilendirme yetkisinin sınırlarını belirleme ve uygulatabilme şansına sahip değillerdir. ${ }^{[98]}$ Merkezi devlet otoritesinin yerini alan feodal düzende kralların beylerin ve derebeyleri vergilendirme yetkisini sınırsız bir biçimde ve keyfi olarak kullanmışlardır. ${ }^{[9]}$

Antidemokratik rejimlerde kuvvetler ayrılığına dayalı bir yetki paylaşımının olmaması, tüm yetkilerin tek bir kişi, zümre veya parti bünyesinde toplanması sonucunu doğurmaktadır. Tüm yetkileri elinde toplayan egemeni sınırlayacak veya dengeleyecek başka hiçbir güç kalmaması onu dilediği her

[97] Özbudun, Türk anayasa hukuku, s.82.

[98] Aktan, C. C., Dileyici, D., Saraç, Ö. (2001). Anayasal vergi reformu ve vergi anayasası önerisi. Kamu Tercihi ve Anayasal İktisat Dergisi, 1(2), s. 22.

[99] Uluatam, Ö. (1995). Türk vergi hukuku. (Genişletilmiş Baskı), Ankara: Seçkin Yayınevi, s. 20. 
an yeni vergiler koymaya veya var olan vergi oranlarını artırmaya yöneltmektedir. Nitekim ilk anayasacılık hareketleri bu sınırsız ve keyfi vergilendirmeler üzerine başlamıştır. Gerçekten en eski anayasal belge olan 1215 tarihli Magna Carta Libertatum İngiliz Kralı'nın sınırsız vergilendirme yetkisine karşı gelişen bir hareket sonucu doğmuştur. ${ }^{[100]}$ Belgenin içeriği incelendiğinde kralın keyfi vergilendirme yetkisinin sınırlandırılmasını amaçlayan ilkelere yer verildiği görülmektedir.

\subsubsection{Demokratik Rejimlerde Vergilendirme Yetkisi}

Bir rejimin demokratik olup olmadığı toplumsal ve siyasal yaşamda bazı unsurların var olup olmadığına göre tespit edilir. Bir devlette bahse konu unsurlar varsa artık o ülkede uygulanan hükümet sistemlerine bakılmaksızın demokratik rejime sahip olduğu söylenebilir. Bu açıdan bakıldığında başkanlık, yarı-başkanlık tipi hükümet sistemleri ve parlamenter hükümet sistemleri arasında bir fark bulunmamaktadır. Hatta monarşilerin de demokratik rejimlerle uyumlu olabileceği savunulmuştur. İngiltere, Belçika, Hollanda, Danimarka, İsveç, Lüksemburg ve Norveç gibi en eski ve köklü demokrasilerin monarşi olması bu görüşü doğrulamaktadır. Bir monarşinin demokrasiyle uyum içerisinde olmasının nedeni sorumsuz ve sembolik devlet başkanının siyasette aktif bir rol almamasıdır.

Modern demokrasinin unsurları konusunda genel kabul gören yaklaşımları bulunan Robert Dahl gerçek anlamda demokrasi (poliarşi) varlığı için asgari yedi şart belirlemiştir. Dahl'a göre;

- Hükümet kararlarını ancak anayasal olarak seçilmiş organlar denetlemelidir.

- Seçilmiş organlar, baskının görülmediği, belirli aralıklarla yapılan ve dürüstçe idare edilen seçimlerle işbaşına gelmelidir.

- İstisnalar dışında tüm yetişkinler seçimle belirlenen organlara seçilebilme olanağına sahip olmalıdır.

- Vatandaşların ülke politikasına ilişkin görüşlerini hiçbir ceza tehdidi olmadan ifade edebilme olanakları olmalıdır.

- Vatandaşlar devletin resmi haber kaynakları dışındaki bilgi kaynaklarına ulaşma imkânlarına sahip olmalıdırlar.

- İstisnalar dışında tüm yetişkinler siyasal organların seçiminde oy hakkına sahip olmalıdırlar.

[100] Çağan, a.g.e., s. 16. 
- Vatandaşlar siyasal organları şekillendirebilme hakkına sahip olma$\operatorname{lidir}^{[101]}$

Dahl'ın önerdiği unsurlardan hareketle demokratik rejimlerde yürütmenin ve yasamanın vergilendirme yetkisini kullanırken diğer anayasal organlarca denetlenmesi gerekmekte olduğu söylenebilir. Gerçekten de ancak gelişmiş demokrasinin var olduğu ülkelerde yasama ve yürütmenin yargisal denetimi ve bu denetimi yürütecek olan yargı bağımsızlığından söz edilebilir. Öte yan dan yasama organı da soru, meclis araştırması, meclis soruşturması, gensoru gibi yollarla yürütmeyi denetleyebilir.

Demokratik rejimlerin temel unsuru olan serbest seçimlerin de vergilendirme derin ve sıkı bir ilgisi vardır. Serbest seçimler siyasal karar alıcılarının belirlenmesi sürecidir. Kamu harcamalarının finansmanı için ne kadar vergi toplanacağı, vergi konularının neler olacağı, vergilendirmenin zamanı, kimden veya hangi kesimden ne kadar vergi alınacağı, hangi konu ve mükelleflerin vergilendirme dışı bırakılacağı, birer siyasal karar alma sorunudur. Sonuç olarak siyasal karar alma mekanizması vergilendirme üzerinde de son derece önemli etkilere sahiptir. Diğer yandan vergilendirme yetkisinin kullanılıp kullanılmaması ve ne şekilde kullanılacağı yakın gelecekte seçim beklentisi olup olmamasına, seçim bölgelerinin durumuna, güçlü bir muhalefetin bulunup bulunmamasına göre değişkenlik gösterebilmektedir. ${ }^{[102]}$ Gerçekten de yaklaşan bir seçim öncesinde siyasal iktidarın vergilendirme yetkisini kullanarak onları vergi yükünün altında bırakması ve seçmenlerin kararlarını olumsuz etkilemesi çoğunlukla söz konusu olamaz. Aksine seçmenlerin üzerindeki vergi yükünün azaltılmasına yönelik kısa vadeli uygulamalar ve vergi aflarına rastlanmaktadır.

Demokratik rejimlerde bireyler ülke politikasına ilişkin görüşlerini hiçbir baskı altında kalmadan açıklayabilmelidirler. Vergilendirmeye ilişkin hususların da aynı kapsamda değerlendirilmesi gereklidir. Bireylerin devletin vergilendirme yetkisine yönelik her türlü görüş eleştirilerinin ve önerilerinin devletçe dinlenilmesi gerekir. Bu noktada devletin topladığ harcadığının bireylerce bilinmesi büyük bir önem arz eder. Bununla ilintili olarak bireylerin kamusal harcamaların vergi türlerine göre kaynağını, bu harcamaların kapsamını, miktarını ve nereye harcandığını ögrenebilme ve bunları denetleyebilmesi de gerekir. Bireylerin bu hakları maliye teorisinde

[101] Dahl, R. A. (1971). Polyarchy: Participation and opposition, New Haven: Yale University Press, s. 7-8.

[102] Gencel, U., Kuru, E. (2012). Vergi kültürü ve vergi politikaları etkileşimi: Türkiye değerlendirmesi, Yönetim Bilimleri Dergisi, 10(20) ss. 29-60, s.37. 
bütçe hakkı olarak adlandırılmıştır. Bütçe hakkı bireylerin ödedikleri vergilerin nereye ve nasıl harcandığını bilme ve bunun hesabını sorma hakkını da içermektedir. ${ }^{[103]}$

\section{SONUÇ}

Vergilendirme yetkisinin kullanımı siyaset kuramlarına, devlet biçimlerine ve siyasi rejimlere göre değişiklik göstermektedir. Siyaset kuramları açısından yapılan ayrıma göre liberalizmin ve sosyalizmin vergilendirme yetkisinin kullanımına bakışı farklılık arz etmektedir. Liberal bakış açısına göre vergilendirme yetkisi minimum kullanılmalıdır. Bunun için de devlet gelir ihtiyacı duyacağı ihtiyari tüm faaliyetlerden uzak durmalıdır. Aynı bakış açısıyla her bireyden geliri oranında vergi alınmalı, bireylerin ödeyecekleri vergi kesin, belirli olmalı, keyfi olmamalı, en uygun zaman ve biçimde alınmalı, vergi toplama maliyetleri minimize edilmelidir. Sosyalist sistemde ise liberalizmin aksine vergilendirme yetkisinin salt işçi sınıfı lehine kullanılması gerektiğini ifade etmektedir.

Devlet biçimlerindeki farklılıklar da vergilendirme yetkisinin kullanımını etkilemektedir. Üniter devletlerde vergilendirme yetkisi merkezi devlet ile mahalli idareler arasında paylaşılmaktadır. Bu tür devletlerde vergilendirme yetkisi doğal olarak merkezi yönetime aitken mahalli idarelere tanınan yetki genel olarak yasa ile belirlenmektedir ve sınırlıdır. Ancak konfederasyonlarda yetki federal devlet, federe devletler ve mahalli idareler arasında federal devlet anayasalarında belirlenmiş kurallara göre paylaştırıllır.

Siyasi rejimlerden antidemokratik rejimlerde isimleri farklı olsa da vergilendirme yetkisi keyfi olarak kullanılır. Demokratik rejimlere geçişte yaşanan siyasal hareketlerin bu sınırsız ve keyfi vergilendirmeler üzerine başlaması bu tezi doğrulamaktadır. Demokratik rejimlerde ise vergilendirme yetkisi anayasal ilkelerle sınırlıdır ve keyfi olarak kullanılamaz. Bunun yanında kamu harcamalarının finansmanı için ne kadar vergi toplanacağı, vergi konularının neler olacağı, vergilendirmenin zamanı, kimden ve hangi kesimden ne kadar vergi alınacağı, hangi konu ve mükelleflerin vergilendirme dışı bırakılacağı demokratik ilkelere göre belirlenir.

Vergilendirme yetkisini inceleyen çalışmalarda, siyaset kuramlarına, devlet biçimlerine ve siyasi rejimlere göre vergilendirme yetkisinin incelenmediği görülmektedir. Bu çalışma bu yönüyle bir ilktir. Bu nedenle vergi teorisine ilişkin çalışmalarda bu ayrımlara göre değerlendirmelere yer verilmesi yerinde

[103] Gürsoy, B., Kamusal Maliye, İkinci Cilt Bütçe, Ankara, A.Ü.S.B.F. Yayınları, 1980. s.56. 
olacaktır.

\section{KAYNAKÇA}

Aksoy, Ş. (1998). Kamu Mâliyesi, İstanbul: Filiz Kitabevi.

Aktan, C. C., Dileyici, D. Saraç, Ö. (2001). Anayasal Vergi Reformu Ve Vergi Anayasası Önerisi. Kamu Tercihi Ve Anayasal İktisat Dergisi, 1(2).

Akyılmaz, B. (1998). Milli Egemenlik Kavramının Gelişimi. Gazi Üniversitesi Hukuk Fakültesi Dergisi,2, 213-222.

Arıkan, Z. Demokratik Gelişim Sürecinde Vergilendirme Yetkisinin Kullanımı Ve Sınırları (Türkiye Analizi), Yayımlanmamış Doktora Tezi, D.E.Ü. S.B.E. İzmir.

Arslan, M., Biniş, M. (2011). İtalya Vergi Sistemi İle Türk Vergi Sisteminin Karşılaştırmalı Analizi. Vergi Sorunları Dergisi, 274.

Birger, N. (2001). The Emergence of Tax Culture in Russia. The 57th Congress of The International Institute of Public Finance: The Role of Political Economy in The Theory And Practice of Public Finance.

Brennan, G., Buchanan, J. M. (1980). The Power to Tax-Analytical Foundations of a Fiscal Constitution, Cambridge: Cambridge University Press.

Çağan, N. (1982). Vergilendirme Yetkisi, İstanbul: Kazancı Hukuk Yayınları.

Çalçalı, Ö. (2013). Kamu Maliyesi Perspektifinden Adam Smith. Uluslararası İktisadi Ve İdari İncelemeler Dergisi, 6(11).

Dahl, R. A. (1971). Polyarchy: Participation And Opposition, New Haven: Yale University Press. Demir, İ. C. (2008). A.B.D. Vergi Sistemi Ve Gelir İdaresi. Afyon Kocatepe Üniversitesi, İ.I.B.F. Dergisi, X(I).

Derdiman, R. C. (2011). Anayasa Hukuku. İstanbul: Alfa Aktüel Yayınları.

Dorn, J. A. Ending Tax Socialism, Http://Www.Cato.Org/Publications/Commentary/ Ending-Tax-Socialism, Son Erişim Tarihi: 24.2.2014.

Erginay, A. (1976). Kamu Maliyesi, Ankara.

Feyzioğlu, B. (1984). Nazari, Tatbiki, Mukayeseli Bütçe. İstanbul: Filiz Kitabevi. 
Gencel, U., Kuru, E. (2012). Vergi Kültürü Ve Vergi Politikalar1 Etkileşimi: Türkiye Değerlendirmesi. Yönetim Bilimleri Dergisi, 10(20), 29-60.

Göze, A. (1995). Liberal Marxiste Faşist Nasyonal Sosyalist Ve Sosyal Devlet, İstanbul: Beta Yayınları.

Gözler, K. (2011). Anayasa Hukukunun Genel Teorisi. Bursa: Ekin Yayınevi.

Gözler, K. (2011). Devletin Genel Teorisi. Bursa: Ekin Yayınevi.

Gözübüyük, A. Ş. (2007). Anayasa Hukuku Anayasa Metni Ve 11. Protokole Göre Hazırlanmış Avrupa İnsan Hakları Sözleşmesi, Ankara: Turhan Kitabevi Yayınları.

Gürsoy, B. (1980). Kamusal Maliye, Bütçe. Ankara: A.Ü.S.B.F. Yayınları.

Herman M. Knoeller, The Power To Tax, 22 Marq. L. Rev. 125 (1938).

Kaneti, S. Vergi Hukuku, (2. Baskı), İstanbul: Filiz Kitabevi.

Nadaroğlu, H. (1998). Mahalli İdareler Teorisi Ekonomisi Uygulaması. İstanbul: Beta Yayınları, İstanbul.

Nalbant, A. (1997). Üniter Devlet Bölgeselleşmeden Küreselleşmeye. Yap1 Kredi Yayınları.

Öncel, M., Çağan, N., Kumrulu, A. (1985). Vergi Hukuku, Ankara: Ankara Üniversitesi Siyasal Bilgiler Fakültesi Yayınları. 1.

Özbudun, E. (2004). Türk Anayasa Hukuku. (8. Baskı), Ankara: Yetkin Yayınları.

Özdemir, S. (2007). Küreselleşme Sürecinde Refah Devleti. İstanbul Ticaret Odası Yayın No: 200757, (2. Baskı), İstanbul: Entegre Matbaacılık.

Özman, M. A. (1964). Devletlerin Egemenliği Ve Milletlerarası Teşekküller. A.Ü.H.F.D., (21), 1-4.

Özpençe, A. İ., Özpençe, Ö. (2007). Küreselleşme Ve Uluslararası Kuruluşların Ulus Devletin Vergilendirme Yetkisine Etkileri. International Journal Of Human Science, 4(1).

Özyörük, M. (1977). İdare Hukuku Ders Notları, Teksir, Ankara. 
Savaş, V. F. (2000). İktisadın Tarihi. (4. Baskı), Ankara: Siyasal Kitabevi.

Schmölders, G. (1982). Genel Vergi Teorisi. (Çev. Salih Turhan), 4. Baskı İstanbul: Fakülteler Matbaası.

Smith, A. (2001). Milletlerin Zenginliği, (Çev. Haldun Derin), İstanbul: Türkiye İş Bankası Kültür Yayınları.

Sur,F. H. (1950). Liberallere Göre Maliye. A.Ü. H.F.D., 7(3-4),567572.

Tunaya, T. Z. (1975). Siyasi Müesseseler Ve Anayasa Hukuku. (3. Bası), İstanbul: Sulhi Garan Matbaası Koll. Şti.

Turhan, S. (1975). Vergileme Ve İktisadi Büyüme. İ.Ü. Maliye Enstitüsü Konferansları, Seri: 23, İstanbul.

Turhan, S. (1982). Vergi Teorisi. İstanbul: Elektronik Ofset Matbaası.

Uluatam, Ö. (1995). Türk Vergi Hukuku. (Genişletilmiş Baskı), Ankara: Seçkin Yayınevi.

Ulusoy, A., Akdemir, T. (2009). Yerel Yönetimler Ve Mali Özerklik:Türkiye Ve OECD Ülkelerinin Karşılaşıtırmalı Analizi. Balıkesir Üniversitesi Sosyal Bilimler Enstitüsü Dergisi, 12(21).

Uygun, O. (2001). Ulusüstü Siyasal Birlikler Ve Küreselleşme, Küreselleşme Ve Ulus Devlet. (Der. M. Koray), İstanbul: Y.T.Ü. Stratejik Araştırmalar Merkezi Yayın1, 151-178.

Uygun, O. (1996). Federal Devlet: Temel İlkeler, Kurumlar Ve Uygulama, İstanbul: Çınar Yayınları.

Quelch, H. (1909). Socialism And Taxation, Social Democrat, Vol. III No.11 November, Pp. 481 -486; Transcribed: By Ted Crawford., Https:// Www. Marxists. Org/Archive/Quelch/1909/11/Taxation.Htm, Son Erişim Tarihi: 24.2.2014)

Yaltı, B. (2010). Anayasa Mimarisinde Bir Yapıtaşı; Mahalli İdarelerin Vergilendirme Yetkisi Üzerine Değerlendirmeler. Vergi Sorunları Dergisi, (261), 7-17.

Yuluğ, M. (1967). Sovyetler Birliği Vergi Sistemi. Maliye Araştırma Merkezi Konferanslar Dergisi, (13). 